\title{
Molecular phylogeny and phylogeography of the freshwater-fish genus Pethia (Teleostei: Cyprinidae) in Sri Lanka
}

\author{
Hiranya Sudasinghe 1,2,3,4 Tharindu Ranasinghe ${ }^{5}$, Jayampathi Herath ${ }^{6}, K^{2}$ umudu Wijesooriya ${ }^{7}$, \\ Rohan Pethiyagoda ${ }^{8}$, Lukas Rüber ${ }^{4,9}$ and Madhava Meegaskumbura ${ }^{6 *}$
}

\begin{abstract}
Background: Sri Lanka is a continental island separated from India by the Palk Strait, a shallow-shelf sea, which was emergent during periods of lowered sea level. Its biodiversity is concentrated in its perhumid south-western 'wet zone'. The island's freshwater fishes are dominated by the Cyprinidae, characterized by small diversifications of species derived from dispersals from India. These include five diminutive, endemic species of Pethia (P. bandula, P. cumingii, P. melanomaculata, P. nigrofasciata, P. reval), whose evolutionary history remains poorly understood. Here, based on comprehensive geographic sampling, we explore the phylogeny, phylogeography and morphological diversity of the genus in Sri Lanka.
\end{abstract}

Results: The phylogenetic analyses, based on mitochondrial and nuclear loci, recover Sri Lankan Pethia as polyphyletic. The reciprocal monophyly of $P$. bandula and $P$. nigrofasciata, and $P$. cumingii and $P$. reval, is not supported. Pethia nigrofasciata, $P$. cumingii, and P. reval show strong phylogeographic structure in the wet zone, compared with P. melanomaculata, which ranges across the dry and intermediate zones. Translocated populations of $P$. nigrofasciata and $P$. reval in the Central Hills likely originate from multiple sources. Morphological analyses reveal populations of $P$. nigrofasciata proximal to P. bandula, a narrow-range endemic, to have a mix of characters between the two species. Similarly, populations of $P$. cumingii in the Kalu basin possess orange fins, a state between the red-finned P. reval from Kelani to Deduru and yellow-finned P. cumingii from Bentara to Gin basins.

Conclusions: Polyphyly in Sri Lankan Pethia suggests two or three colonizations from mainland India. Strong phylogeographic structure in P. nigrofasciata, P. cumingii and P. reval, compared with P. melanomaculata, supports a model wherein the topographically complex wet zone harbors greater genetic diversity than the topographically uniform dry-zone. Mixed morphological characters between P. bandula and P. nigrofasciata, and P. cumingii and P. reval, and their unresolved phylogenies, may suggest recent speciation scenarios with incomplete lineage sorting, or hybridization.

Keywords: Smiliogastrinae, Morphology, Barb, Biodiversity hotspot, India

*Correspondence: madhava_m@mac.com

${ }^{6}$ Guangxi Key Laboratory for Forest Ecology and Conservation, College

of Forestry, Guangxi University, Nanning 530004, Guangxi, People's

Republic of China

Full list of author information is available at the end of the article

\section{Background}

As part of a global biodiversity hotspot, the $65,000 \mathrm{~km}^{2}$ island of Sri Lanka contains remarkable biotic endemism $[1,2]$. The island is narrowly separated from India by the $\sim 25 \mathrm{~km}$ wide Palk Strait, a shallow-shelf sea. Marine regressions in excess of $10 \mathrm{~m}$ have been frequent since the Oligocene [3], giving rise to a wide land bridge (the Palk 
Isthmus) connecting Sri Lanka and India $[4,5]$. Despite Sri Lanka's Gondwanan origins [6], its vertebrate fauna lacks a clear Gondwanan signature except in the case of a single lineage of amphibians [7]. Thus, the Palk Isthmus has been the only route for the dispersal of aquatic organisms between the mainland and Sri Lanka. Despite periodic inundations during sea-level high stands, the isthmus has been exposed for most of the past $15 \mathrm{My}$ and until as recently as 10 kya $[3,8]$.

Endemism in the island, which is part of the Western Ghats-Sri Lanka Biodiversity Hotspot [9], is concentrated in its hilly, perhumid south-western wet zone (rainfall $>2.5 \mathrm{~m} / \mathrm{y}$ ), characterized by mixed-dipterocarp rainforests and complex topography [2]. By contrast, the topographically uniform dry zone (rainfall $<1.8 \mathrm{~m} / \mathrm{y}$ ) is markedly more seasonal, characterized by deciduous forest with relatively low endemism. Between these is a narrow 'intermediate zone' [2].

Despite extensive terrestrial connectivity with the mainland, however, biotic exchange across the Palk Isthmus appears to have been strongly mediated by climate $[5,8,10]$. Arid conditions on the isthmus led, especially during the Plio-Pleistocene, to it serving more as a filter than a conduit for biotic exchange $[5,8,10,11]$. Hence, much of the island's remarkable biodiversity derives from insular diversifications stemming from a small number of immigrant dispersals, as in the case of its 59 endemic treefrog species and 50 endemic crab species, shown to be monophyletic by Meegaskumbura et al. [12] and Beenaerts et al. [13], respectively. The same has been shown to be true also for several freshwater-fish diversifications, such as in the cypriniform genera Devario, Rasbora and Systomus $[11,14,15]$.

The cyprinid genus Pethia presently includes some 43 valid species (Additional file 1: Table S1), nine of which have been discovered since the genus was first described by Pethiyagoda et al. [16] [see: 17]. Pethia have a wide distribution, ranging from Sri Lanka across India and on to Myanmar [16, 18-21]. They are colorful, usually sexually dimorphic fishes that have long been popular in the global ornamental-fish trade [22]. Members of the genus are united by a suite of characters (none of them exclusive) that include small size (standard length up to about $5 \mathrm{~cm}$ ), a posteriorly serrated last unbranched dorsal-fin ray, having the lateral line (usually) incomplete, and exhibiting between one and three black blotches, bars or spots on the side of the body, usually including one in the humeral-cleithral region and another above the anal fin or on the caudal peduncle [16]. Although the phylogenetic relationships of Pethia to the genera formerly referred to Puntius sensu lato, in which the genus was subsumed prior to Pethiyagoda et al. [16], remain only weakly supported, several molecular studies have shown Pethia to be monophyletic [10, 11, 23-26]. Phylogenetic relationships within the genus, however, remain to be elucidated.

Five species of Pethia have been reported from Sri Lanka: Pethia bandula, P. cumingii, P. nigrofasciata, $P$. reval and $P$. melanomaculata, all of them endemic $[27,28]$. The genus is widely distributed in the island's major habitat types, from sea level to elevations of about $1000 \mathrm{~m}$ above sea level (a.s.l) [22, 27]. The first three species are endemic to the wet zone, while the last occurs in the dry and intermediate zones. Pethia reval ranges from the Kelani basin in the wet-zone to the Deduru basin in the intermediate zone, while P. bandula is a narrowrange endemic confined to a short stretch of a single wetzone stream draining the Kelani basin [22, 27-29]. Pethia reval and $P$. cumingii are distinguished primarily by fin coloration: red in the former and yellow in the latter [28].

The four wet-zone species, as a group, differ from Pethia melanomaculata in exhibiting near-complete allopatry as well as a coloration that includes two or three black bars on the body, compared with a small black spot on the humeral region and a blotch on the caudal peduncle of $P$. melanomaculata. This and other differences in morphology [27-29] lead us to hypothesize that the Sri Lankan diversification of Pethia is not monophyletic.

\footnotetext{
(See figure on next page.)

Fig. 1 a Sri Lanka, showing the geographical origin of samples of Pethia nigrofasciata and P. bandula used in this study. The thin black lines indicate basin boundaries, while the bold black line indicates the 2000-mm isohyet, which encompasses the wet zone. Numbers on the map (a) represent the sampling localities listed in Table 1. b close-up of the sampling localities for P. nigrofasciata in the headwaters of the Attanagalu basin neighboring the type locality of $P$. bandula. These populations show a mix of meristic characters and color patterns intermediate between P. nigrofasciata and P. bandula. In $\mathbf{d}-\mathbf{r}$, specimens with complete and incomplete pored lateral-line scales are represented by black and white squares, respectively while those with complete bar beneath dorsal fin and those without or an incomplete are represented by black and white circles, respectively. Numbers on the map $(\mathbf{b})$ are referenced to the specimens illustrated in $(\mathbf{g}-\mathbf{n})$ in parentheses. $\mathbf{c}$ Live coloration of $P$. bandula. $\mathbf{d}$ Holotype of $P$. bandula, ZRC 38,483, $34.6 \mathrm{~mm} \mathrm{SL}$, e paratype CMK 7146C, $31.6 \mathrm{~mm} \mathrm{SL}$, and f paratype, CMK 7146D, $30.8 \mathrm{~mm}$ SL of $P$. bandula. Pethia cf. nigrofasciata from the Attanagalu basin in $\mathbf{g - n} . \mathbf{g}$ DZ5353F, $40.3 \mathrm{~mm}$ SL (2). $\mathbf{h}$ DZ4452C, $38.8 \mathrm{~mm}$ SL (5). i DZ4452A, 36.9 mm SL (5). j DZ5352B, 39.0 mm SL (2). k DZ5350E, 42.6 mm SL (4). I DZ5351I, 37.1 mm SL (3). $\mathbf{m}$ DZ5350G, 35.7 mm SL (4). $\mathbf{n}$ DZ5351 A, 34.8 mm SL (3). o Live coloration of P. nigrofasciata. Pethia nigrofasciata in p-r. p DZ4403A, 39.1 mm SL, Kelani basin. q DZ4059B, $32.3 \mathrm{~mm}$ SL, Bentara basin. r DZ4509B, 44.2 mm SL, Walawe basin
} 


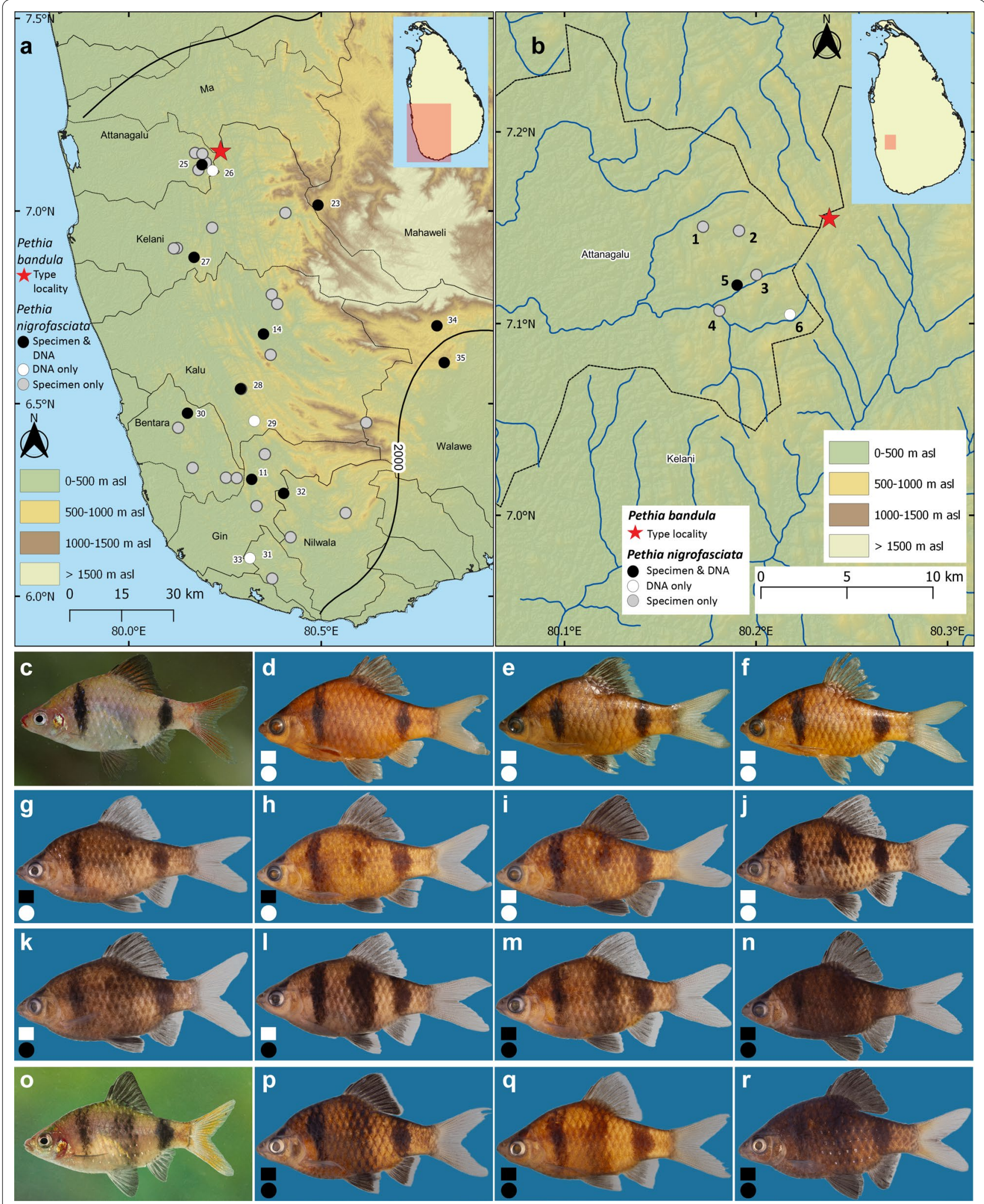

Fig. 1 (See legend on previous page.) 


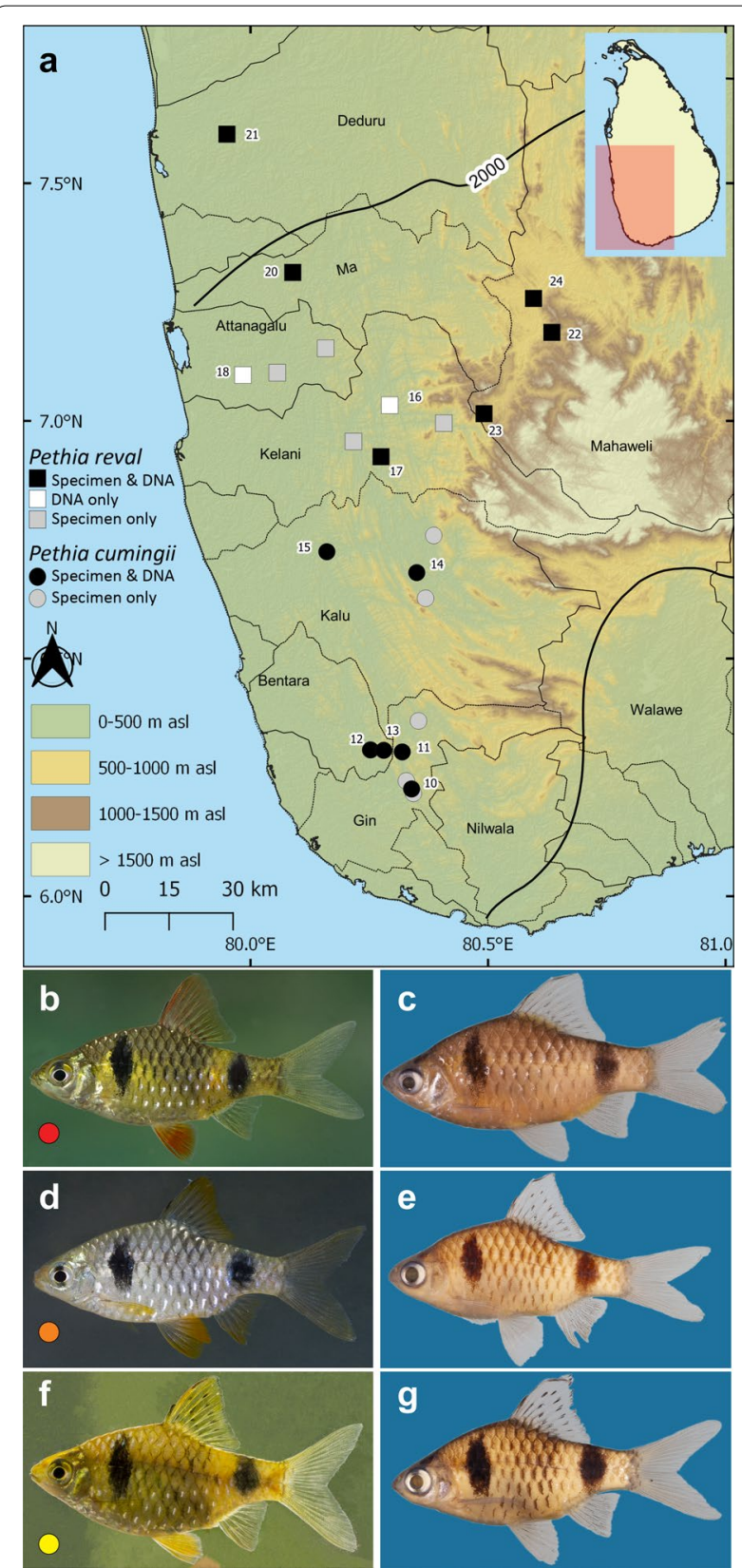

Fig. 2 a Sri Lanka, showing the geographical origin of samples of Pethia cumingii and P. reval used in this study. The thin black lines indicate basin boundaries, while the bold black line indicates the 2000-mm isohyet, which encompasses the wet zone. Numbers on the map represent the sampling localities listed in Table 1. Pethia reval in b live coloration and $\mathbf{c}$ in preservation, DZ5354A, $30.9 \mathrm{~mm} \mathrm{SL}$, Attanagalu basin. Population of P. cf. cumingii from Kalu basin with orange fins in (d) live coloration and e in preservation, DZ3917A, $30.8 \mathrm{~mm} \mathrm{SL}$. Pethia cumingii from southerly basins (here Gin) in (f) live coloration and $\mathbf{g}$ in preservation, DZ5014A, $27.8 \mathrm{~mm} \mathrm{SL}$

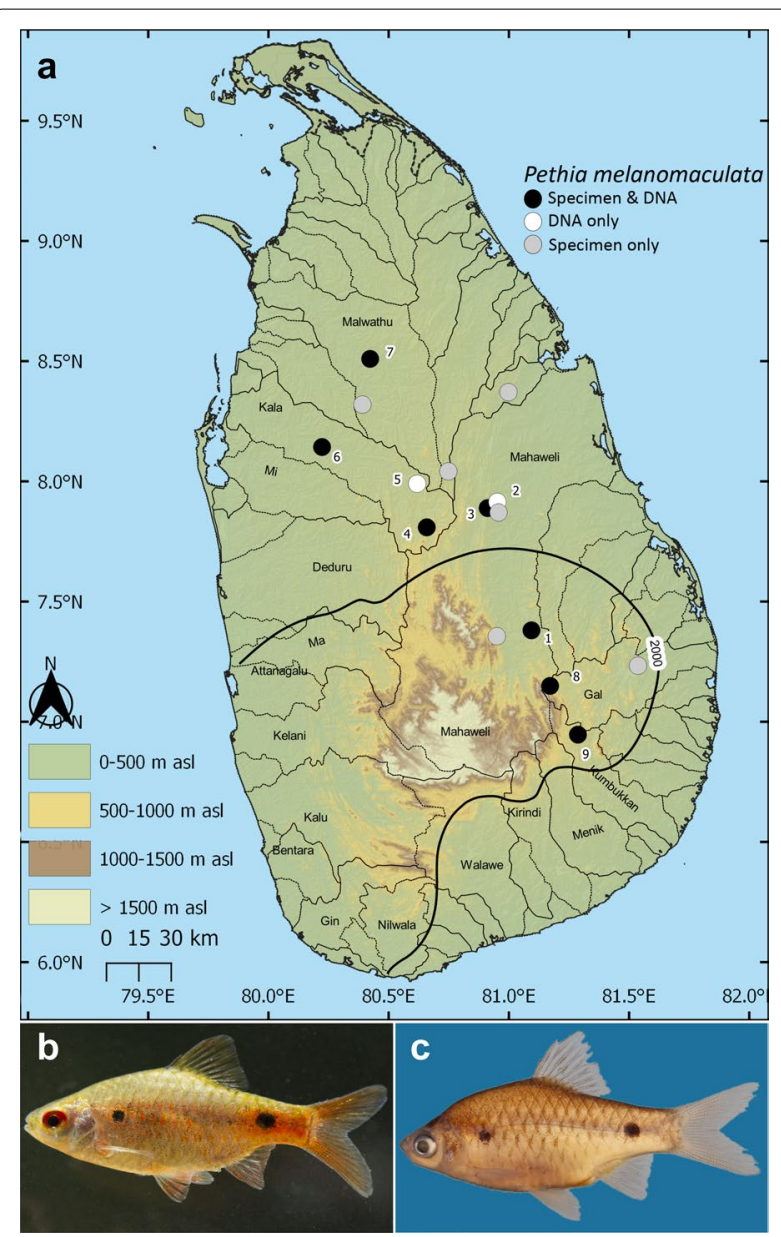

Fig. 3 a Sri Lanka, showing the geographical origin of samples of Pethia melanomaculata used in this study. The thin black lines indicate basin boundaries, while the bold black line indicates the 2000-mm isohyet, which encompasses the wet zone. Numbers on the map represent the sampling localities listed in Table 1. Pethia melanomaculata in $\mathbf{b}$ live coloration and $\mathbf{c}$ in preservation, DZ4104, $34.1 \mathrm{~mm}$ SL, Mahaweli basin

The wet-zone species appear to comprise a monophyletic diversification, while $P$. melanomaculata seems more closely related to P. punctata, a South Indian species [27, 30,31]. Additionally, the wet-zone species have unusual distributions. While $P$. reval and $P$. cumingii are apparently allopatric, $P$. nigrofasciata occurs in sympatry with both; and while the range of $P$. bandula lies within the range of both $P$. nigrofasciata and $P$. reval, $P$. bandula does not occur in syntopy with either. Given the wet-zone's more complex topography, we hypothesize that the three widespread wet-zone species $(P$, reval, $P$. 
Table 1 Details of samples of Sri Lankan Pethia from which sequences were generated, with their localities, voucher references and GenBank accession numbers. LK, Sri Lanka

\begin{tabular}{|c|c|c|c|c|c|c|}
\hline Voucher & Location & GPS coordinates & cytb & cytb haplotype & rag1 & rag1 haplotype \\
\hline \multicolumn{7}{|c|}{ Pethia melanomaculata } \\
\hline DZ1500 & LK: Ulhitiya, Mahaweli (01) & 7.3799 N $81.0939 \mathrm{E}$ & MT732729 & M3 & MT732764 & M1 \\
\hline DZ1501 & LK: Ulhitiya, Mahaweli (01) & 7.3799 N $81.0939 E$ & MZ686566 & M3 & - & - \\
\hline DZ4302 & LK: Angammedilla, Mahaweli (02) & 7.9140 N $80.9520 E$ & MZ686567 & M3 & MZ686661 & M1 \\
\hline DZ4303 & LK: Angammedilla, Mahaweli (03) & 7.8884 N $80.9116 E$ & MZ686568 & M4 & - & - \\
\hline DZ4536 & LK: Dambulu Oya, Dambulla, Kala (04) & 7.8083 N $80.6584 E$ & MZ686569 & M1 & MZ686662 & M1 \\
\hline DZ4793 & LK: Maha Elagamuwa, Kala (05) & 7.9898 N $80.6184 \mathrm{E}$ & MZ686570 & M1 & MZ686663 & M1 \\
\hline DZ4885 & LK: Rajanganaya, Kala (06) & $8.1415 \mathrm{~N} 80.2211 \mathrm{E}$ & MZ686571 & M1 & MZ686664 & M1 \\
\hline DZ5094 & LK: Medawacchiya, Malwathu (07) & $8.5091 \mathrm{~N} 80.4229 \mathrm{E}$ & MZ686572 & M1 & MZ686665 & M1 \\
\hline DZ5095 & LK: Medawacchiya, Malwathu (07) & $8.5091 \mathrm{~N} 80.4229 \mathrm{E}$ & MZ686573 & M2 & - & - \\
\hline DZ4570 & LK: Kotagama, Gal (08) & $7.1485 \mathrm{~N} 81.1715 \mathrm{E}$ & MZ686574 & M5 & MZ686666 & M2 \\
\hline DZ4583 & LK: Bellan Oya, Kumbukkan (09) & 6.9458 N $81.2874 E$ & MZ686575 & M6 & MZ686667 & M1 \\
\hline DZ4584 & LK: Bellan Oya, Kumbukkan (09) & 6.9458 N $81.2874 \mathrm{E}$ & MZ686576 & M7 & - & - \\
\hline \multicolumn{7}{|c|}{ Pethia cumingii } \\
\hline DZ5037 & LK: Homadola, Gin (10) & 6.2254 N $80.339 \mathrm{E}$ & MZ686577 & C9 & MZ686668 & $\mathrm{R} 1$ \\
\hline DZ5038 & LK: Homadola, Gin (10) & 6.2254 N $80.339 E$ & MZ686578 & C9 & - & - \\
\hline DZ5039 & LK: Homadola, Gin (10) & 6.2254 N $80.339 E$ & MZ686579 & C9 & - & - \\
\hline DZ4959 & LK: Hiniduma, Gin (11) & 6.3033 N $80.3193 E$ & MZ686580 & C6 & MZ686669 & $\mathrm{R} 1$ \\
\hline DZ4960 & LK: Hiniduma, Gin (11) & 6.3033 N $80.3193 E$ & MZ686581 & $\mathrm{C} 8$ & MZ686670 & R1 \\
\hline DZ4961 & LK: Hiniduma, Gin (11) & 6.3033 N $80.3193 E$ & MZ686582 & C9 & - & - \\
\hline DZ4962 & LK: Hiniduma, Gin (11) & 6.3033 N $80.3193 E$ & MZ686583 & C5 & - & - \\
\hline DZ4963 & LK: Hiniduma, Gin (11) & 6.3033 N $80.3193 \mathrm{E}$ & MZ686584 & C7 & - & - \\
\hline DZ3305 & LK: Bambarawana, Mattaka, Bentara (12) & 6.3076 N $80.2524 \mathrm{E}$ & MT732731 & C4 & MT732766 & R1 \\
\hline WHT01 & LK: Bambarawana, Mattaka, Bentara (13) & 6.3067 N $80.2804 \mathrm{E}$ & MZ686585 & C5 & MZ686671 & R1 \\
\hline DZ3026 & LK: Ratnapura, Elapatha, Kalu (14) & 6.6805 N $80.3499 E$ & MZ686586 & $\mathrm{C} 2$ & MZ686672 & R1 \\
\hline DZ3056 & LK: Ratnapura, Elapatha, Kalu (14) & 6.6805 N $80.3499 E$ & MZ686587 & $\mathrm{C} 1$ & MZ686673 & R4 \\
\hline DZ3117 & LK: Dombagaskanda, Kalu (15) & 6.7245 N $80.1606 E$ & MZ686588 & C3 & - & - \\
\hline DZ3118 & LK: Dombagaskanda, Kalu (15) & 6.7245 N $80.1606 E$ & MZ686589 & $\mathrm{C} 2$ & MZ686674 & R3 \\
\hline DZ3119 & LK: Dombagaskanda, Kalu (15) & 6.7245 N $80.1606 E$ & MZ686590 & $\mathrm{C} 1$ & MZ686675 & R2 \\
\hline \multicolumn{7}{|l|}{ Pethia reval } \\
\hline WHT03 & LK: Yatiyanthota, Kelani (16) & 7.0329 N $80.2929 E$ & MZ686591 & R8 & MZ686676 & R1 \\
\hline DZ4999 & LK:Yogama, Kelani (17) & 6.9245 N $80.2746 E$ & MZ686592 & R7 & MZ686677 & $\mathrm{R} 1$ \\
\hline DZ5000 & LK: Yogama, Kelani (17) & 6.9245 N $80.2746 E$ & MZ686593 & R8 & MZ686678 & $\mathrm{R} 1$ \\
\hline DZ5001 & LK: Yogama, Kelani (17) & 6.9245 N $80.2746 E$ & MZ686594 & R8 & - & - \\
\hline DZ5002 & LK: Yogama, Kelani (17) & 6.9245 N $80.2746 E$ & MZ686595 & R8 & - & - \\
\hline DZ5003 & LK:Yogama, Kelani (17) & 6.9245 N $80.2746 E$ & MZ686596 & R8 & - & - \\
\hline DZ3007 & LK: Gampaha, Attanagalu (18) & 7.0962 N 79.984 E & MZ686597 & R5 & - & - \\
\hline DZ3091 & LK: Gampaha, Attanagalu (18) & 7.0962 N 79.984 E & MZ686598 & R5 & - & - \\
\hline DZ5032 & LK: Yakkala, Attanagalu (19) & 7.0792 N $80.0732 \mathrm{E}$ & MZ686599 & R5 & MZ686679 & R1 \\
\hline DZ5033 & LK:Yakkala, Attanagalu (19) & $7.0792 \mathrm{~N} 80.0732 \mathrm{E}$ & MZ686600 & R5 & MZ686680 & $\mathrm{R} 1$ \\
\hline DZ5034 & LK: Yakkala, Attanagalu (19) & 7.0792 N $80.0732 \mathrm{E}$ & MZ686601 & R6 & - & - \\
\hline DZ5035 & LK: Yakkala, Attanagalu (19) & 7.0792 N $80.0732 \mathrm{E}$ & MZ686602 & C9 & - & - \\
\hline DZ5036 & LK: Yakkala, Attanagalu (19) & 7.0792 N $80.0732 \mathrm{E}$ & MZ686603 & C9 & - & - \\
\hline DZ4385 & LK: Bopitiya, Giriulla, Ma (20) & $7.3121 \mathrm{~N} 80.0888 \mathrm{E}$ & MZ686604 & R3 & MZ686681 & R1 \\
\hline DZ4386 & LK: Bopitiya, Giriulla, Ma (20) & $7.3121 \mathrm{~N} 80.0888 \mathrm{E}$ & MZ686605 & R4 & MZ686682 & R1 \\
\hline DZ4828 & LK: Bopitiya, Giriulla, Ma (20) & $7.3121 \mathrm{~N} 80.0888 \mathrm{E}$ & MZ686606 & R5 & MZ686683 & $\mathrm{R} 1$ \\
\hline DZ4829 & LK: Bopitiya, Giriulla, Ma (20) & $7.3121 \mathrm{~N} 80.0888 \mathrm{E}$ & MZ686607 & R3 & MZ686684 & R1 \\
\hline DZ4830 & LK: Bopitiya, Giriulla, Ma (20) & $7.3121 \mathrm{~N} 80.0888 \mathrm{E}$ & MZ686608 & R5 & - & - \\
\hline
\end{tabular}


Table 1 (continued)

\begin{tabular}{|c|c|c|c|c|c|c|}
\hline Voucher & Location & GPS coordinates & cytb & cytb haplotype & $\operatorname{rag} 1$ & rag1 haplotype \\
\hline DZ3039 & LK: Kolamunu Oya, Deduru (21) & 7.6029 N $79.9502 \mathrm{E}$ & MZ686609 & R2 & - & - \\
\hline DZ3061 & LK: Kolamunu Oya, Deduru (21) & 7.6029 N $79.9502 E$ & MT732730 & R1 & MT732765 & R1 \\
\hline DZ4823 & LK: Nillamba, Hindagala, Mahaweli (22) & $7.1861 \mathrm{~N} 80.6344 \mathrm{E}$ & MZ686610 & R11 & - & - \\
\hline DZ4824 & LK: Nillamba, Hindagala, Mahaweli (22) & $7.1861 \mathrm{~N} 80.6344 \mathrm{E}$ & MZ686611 & R11 & - & - \\
\hline DZ4825 & LK: Nillamba, Hindagala, Mahaweli (22) & $7.1861 \mathrm{~N} 80.6344 \mathrm{E}$ & MZ686612 & R11 & - & - \\
\hline DZ4826 & LK: Nillamba, Hindagala, Mahaweli (22) & $7.1861 \mathrm{~N} 80.6344 \mathrm{E}$ & MZ686613 & R11 & - & - \\
\hline DZ4827 & LK: Nillamba, Hindagala, Mahaweli (22) & $7.1861 \mathrm{~N} 80.6344 \mathrm{E}$ & MZ686614 & R10 & - & - \\
\hline DZ3238 & LK: Ambagamuwa, Mahaweli (23) & $7.0151 \mathrm{~N} 80.4915 \mathrm{E}$ & MZ686615 & R9 & - & - \\
\hline DZ3239 & LK: Ambagamuwa, Mahaweli (23) & $7.0151 \mathrm{~N} 80.4915 \mathrm{E}$ & MZ686616 & R8 & MZ686685 & R1 \\
\hline DZ3240 & LK: Ambagamuwa, Mahaweli (23) & $7.0151 \mathrm{~N} 80.4915 \mathrm{E}$ & MZ686617 & R8 & MZ686686 & R1 \\
\hline DZ3241 & LK: Ambagamuwa, Mahaweli (23) & $7.0151 \mathrm{~N} 80.4915 \mathrm{E}$ & MZ686618 & R8 & - & - \\
\hline DZ3256 & LK: Ambagamuwa, Mahaweli (23) & $7.0151 \mathrm{~N} 80.4915 \mathrm{E}$ & MZ686619 & R9 & - & - \\
\hline DZ3255 & LK: Ambagamuwa, Mahaweli (23) & $7.0151 \mathrm{~N} 80.4915 \mathrm{E}$ & MZ686620 & R9 & - & - \\
\hline DZ3257 & LK: Ambagamuwa, Mahaweli (23) & $7.0151 \mathrm{~N} 80.4915 \mathrm{E}$ & MZ686621 & R8 & - & - \\
\hline DZ3278 & LK: Sarasavi Oya, Peradeniya, Mahaweli (24) & $7.2574 \mathrm{~N} 80.5957 \mathrm{E}$ & MZ686622 & R9 & MZ686687 & R1 \\
\hline \multicolumn{7}{|c|}{ Pethia nigrofasciata } \\
\hline DZ4449 & LK: Alawala, Attanagalu (25) & $7.12 \mathrm{~N} 80.1901 \mathrm{E}$ & MZ686623 & N1 & MZ686688 & N1 \\
\hline DZ4450 & LK: Alawala, Attanagalu (25) & $7.12 \mathrm{~N} 80.1901 \mathrm{E}$ & MZ686624 & N2 & MZ686689 & N1 \\
\hline DZ4451 & LK: Alawala, Attanagalu (25) & $7.12 \mathrm{~N} 80.1901 \mathrm{E}$ & MZ686625 & N3 & - & - \\
\hline DZ5040 & LK: Alawala, Attanagalu (25) & $7.12 \mathrm{~N} 80.1901 \mathrm{E}$ & MZ686626 & N1 & MZ686690 & N1 \\
\hline DZ5145 & LK: Lenagala, Attanagalu (26) & 7.1047 N $80.2177 \mathrm{E}$ & MZ686627 & N2 & MZ686691 & N1 \\
\hline DZ4343 & LK: Illukowita, Thummodara, Kelani (27) & 6.8796 N 80.1694 E & MZ686628 & N4 & MZ686692 & N1 \\
\hline DZ4344 & LK: Illukowita, Thummodara, Kelani (27) & 6.8796 N $80.1694 \mathrm{E}$ & MZ686629 & N5 & - & - \\
\hline DZ3024 & LK: Ratnapura, Elapatha, Kalu (14) & 6.6805 N $80.3499 E$ & MZ686630 & N6 & - & - \\
\hline DZ3025 & LK: Ratnapura, Elapatha, Kalu (14) & 6.6805 N $80.3499 E$ & MZ686631 & N7 & - & - \\
\hline DZ3367 & LK: Athwelthota, Kalu (28) & 6.5382 N $80.2901 E$ & MZ686632 & N9 & MZ686693 & N1 \\
\hline DZ4769 & LK: Runakanda Forest, Kalu (29) & 6.4548 N $80.3263 \mathrm{E}$ & MZ686633 & N8 & MZ686694 & $\mathrm{N} 1$ \\
\hline DZ4770 & LK: Runakanda Forest, Kalu (29) & 6.4548 N $80.3263 \mathrm{E}$ & MZ686634 & N8 & - & - \\
\hline DZ3095 & LK: Thundola, Horawala, Bentara (30) & 6.475 N $80.1524 E$ & MT732732 & N11 & MT732767 & N4 \\
\hline DZ3096 & LK: Thundola, Horawala, Bentara (30) & 6.475 N 80.1524 E & MZ686635 & N10 & MZ686695 & N4 \\
\hline DZ4964 & LK: Hiniduma, Gin (11) & 6.3033 N 80.3193 E & MZ686636 & N12 & MZ686696 & N2 \\
\hline DZ4965 & LK: Hiniduma, Gin (11) & 6.3033 N 80.3193 E & MZ686637 & N13 & - & - \\
\hline DZ4928 & LK: Kottawa Forest, Galle, Gin (31) & 6.0986 N $80.3146 E$ & MZ686638 & N14 & MZ686697 & N3 \\
\hline DZ4929 & LK: Kottawa Forest, Galle, Gin (31) & 6.0986 N $80.3146 E$ & MZ686639 & N14 & - & - \\
\hline DZ4930 & LK: Kottawa Forest, Galle, Gin (31) & 6.0986 N $80.3146 E$ & MZ686640 & N15 & - & - \\
\hline DZ4478 & LK: Ugudu dola, Opatha, Nilwala (32) & $6.2669 \mathrm{~N} 80.4023 \mathrm{E}$ & MZ686641 & N17 & MZ686698 & N2 \\
\hline DZ4479 & LK: Ugudu dola, Opatha, Nilwala (32) & $6.2669 \mathrm{~N} 80.4023 \mathrm{E}$ & MZ686642 & N18 & MZ686699 & N2 \\
\hline DZ5060 & LK: Kotapola, Nilwala (33) & 6.2949 N 80.544 E & MZ686643 & N16 & MZ686700 & N1 \\
\hline DZ5061 & LK: Kotapola, Nilwala (33) & 6.2949 N 80.544 E & MZ686644 & N16 & MZ686701 & N1 \\
\hline DZ5062 & LK: Kotapola, Nilwala (33) & 6.2949 N 80.544 E & MZ686645 & N16 & - & - \\
\hline DZ1454 & LK: Pambahinna, Walawe (34) & 6.7018 N $80.8006 \mathrm{E}$ & MZ686646 & N19 & - & - \\
\hline DZ4244 & LK: Rajawaka, near Kaltota, Walawe (35) & 6.6064 N $80.8195 E$ & MZ686647 & N19 & MZ686702 & N2 \\
\hline DZ4245 & LK: Rajawaka, near Kaltota, Walawe (35) & 6.6064 N 80.8195 E & MZ686648 & N19 & MZ686703 & N1 \\
\hline DZ3233 & LK: Ambagamuwa, Mahaweli (23) & $7.0151 \mathrm{~N} 80.4915 \mathrm{E}$ & MZ686649 & N6 & MZ686704 & N1 \\
\hline DZ3234 & LK: Ambagamuwa, Mahaweli (23) & $7.0151 \mathrm{~N} 80.4915 \mathrm{E}$ & MZ686650 & N23 & - & - \\
\hline DZ3236 & LK: Ambagamuwa, Mahaweli (23) & $7.0151 \mathrm{~N} 80.4915 \mathrm{E}$ & MZ686651 & $\mathrm{N} 22$ & - & - \\
\hline DZ3237 & LK: Ambagamuwa, Mahaweli (23) & $7.0151 \mathrm{~N} 80.4915 \mathrm{E}$ & MZ686652 & N5 & - & - \\
\hline DZ3263 & LK: Ambagamuwa, Mahaweli (23) & $7.0151 \mathrm{~N} 80.4915 \mathrm{E}$ & MZ686653 & N5 & - & - \\
\hline DZ3264 & LK: Ambagamuwa, Mahaweli (23) & 7.0151 N 80.4915 E & MZ686654 & N23 & - & - \\
\hline
\end{tabular}


Table 1 (continued)

\begin{tabular}{cllllll}
\hline Voucher & Location & GPS coordinates & cytb & cytb haplotype & rag1 & rag1 haplotype \\
\hline DZ3265 & LK: Ambagamuwa, Mahaweli (23) & 7.0151 N 80.4915 E & MZ686655 & N20 & - & - \\
DZ3266 & LK: Ambagamuwa, Mahaweli (23) & 7.0151 N 80.4915 E & MZ686656 & N6 & - & - \\
DZ3267 & LK: Ambagamuwa, Mahaweli (23) & 7.0151 N 80.4915 E & MZ686657 & N21 & - & - \\
DZ3268 & LK: Ambagamuwa, Mahaweli (23) & 7.0151 N 80.4915 E & MZ686658 & N23 & - & - \\
DZ3269 & LK: Ambagamuwa, Mahaweli (23) & 7.0151 N 80.4915 E & MZ686659 & N20 & - & - \\
DZ3270 & LK: Ambagamuwa, Mahaweli (23) & 7.0151 N 80.4915 E & MZ686660 & N20 & - & - \\
\hline
\end{tabular}

cumingii, and P. nigrofasciata) exhibit strong phylogeographic structure in comparison to $P$. melanomaculata, which occurs across the topographically uniform dryzone plains.

Most studies that have referenced Pethia in South Asia up to now have involved new-species descriptions. Here, based on a sampling of 35 locations in 14 major river basins in Sri Lanka (Figs. 1a, 2a, 3a), and based on a mitochondrial and nuclear DNA dataset, we analyze, for the first time, the phylogeography and phylogenetic relationships of Pethia in the island in the context of representatives of the genus in India. Based on these, we evaluate the hypotheses set out above.

Further, several translocated populations of $P$. nigrofasciata and P. reval are documented from the Mahaweli basin in the Central Hills [22, 32-34]. However, the origin of the translocated stock has until now not been established. Here, using our molecular dataset representative of both translocated and native populations of these two species, we seek to establish the provenance of these introduced populations. Finally, based on both molecular and morphometric data, we investigate the species-diversity of Pethia in Sri Lanka following the general-lineage concept of species [35], and delineate the geographic distributions of the species.

\section{Results}

\section{Molecular phylogeny}

The $c y t b$ and rag1 phylogenetic analyses recovered mostly similar topologies with respect to the relationships of Sri Lankan species of Pethia in both the ML and the BI frameworks, with differences observed mainly in branch lengths. Here we focus on the concatenated $c y t b+$ rag1 dataset (Fig. 4). Differences between the single-gene and concatenated datasets are mentioned, where necessary.

While the monophyly of Pethia is supported, with strong node support, in all the analyses (Fig. 4), the sistergroup relationships of the genus are not clearly resolved. The South Indian genus Haludaria is recovered as the sister group of Pethia in the concatenated $c y t b+$ rag1 BI and $\mathrm{ML}$ phylogenies $(\mathrm{PP}=98, \mathrm{BP}<50)$, and the cytb $\mathrm{BI}$ phylogeny $(\mathrm{PP}=70)$, with moderate to weak node support (Fig. 4, Additional file 1: Fig. S1). In the cytb ML phylogeny, the clade of Systomus + Afrotropical small barbs is recovered as the sister group of Pethia, but with weak node support $(\mathrm{BP}<50)$. In the rag1 $\mathrm{BI}$ and ML phylogenies, the sister group of Pethia is a clade of Southeast Asian barbs represented by the genera Barbodes, Desmopuntius, Hampala, Puntigrus, Oliotius, and Striuntius, but with weak node support $(\mathrm{PP}=78, \mathrm{BP}<50$, Additional file 1: Fig. S2).

The Sri Lankan species of Pethia are recovered as polyphyletic in all the analyses (Fig. 4, Additional file 1: Figs. S1, S2). A clade represented by GenBank sequences of Pethia from Uttar Pradesh (North India) and Thailand (Southeast Asia), identified either as "P. ticto" or "P. stoliczkana", is recovered as the sister group of Pethia melanomaculata in the BI and ML analysis of the concatenated $(\mathrm{PP}=83, \mathrm{BP}<50)$ and $\mathrm{BI}$ cytb phylogenies $(\mathrm{PP}<50)$, but with weak node support (Fig. 4, Additional file 1: S1). In the ML cytb phylogeny, P. melanomaculata is recovered as the sister group of the clades that include P. nigrofasciata, $P$. cumingii, $P$. reval, $P$. ticto, P. longicauda and $P$. pookodensis, but with weak node support $(\mathrm{BP}<50)$. In the rag1 phylogeny, the GenBank sequence identified as "P. stoliczkana" is recovered as the sister group

(see figure on next page)

Fig. 4 Molecular phylogenetic relationships of Pethia, based on Bayesian inference of the concatenated cytb + rag 1 (2572 bp) data set. Asterisks $\left.{ }^{*}\right)$ above and below nodes represent $\geq 95 \%$ Bayesian posterior probabilities and ML bootstrap values, respectively. Scale bar represents number of changes per site. Node support below 50 is not labeled. Results of the molecular species delimitation methods (PTP, mPTP and ABGD) for cytb are shown as grey rectangles on the right. The results of the ABGD shown are based on the initial partition using the $p$-distance model at $p=\sim 0.01$ and $X=1.5$. The GenBank sample "P. meingangbii" is represented by only a rag1 sequence (KJ548126) and is not included in the species delimitation analyses. In the mPTP analysis, P. nigripinna (MG199967) and "Pethia sp." (MT483288) were delimited as a single species 


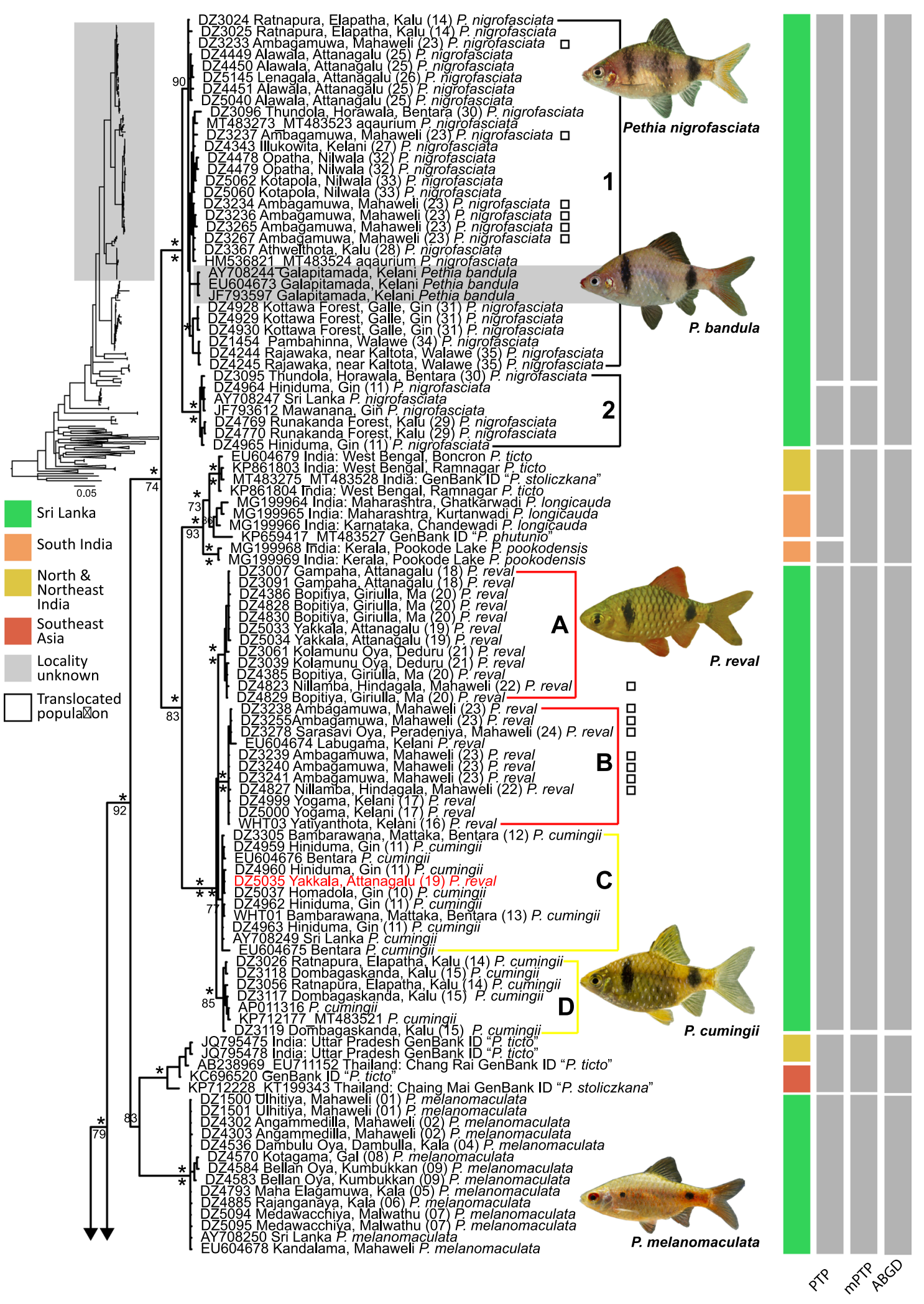



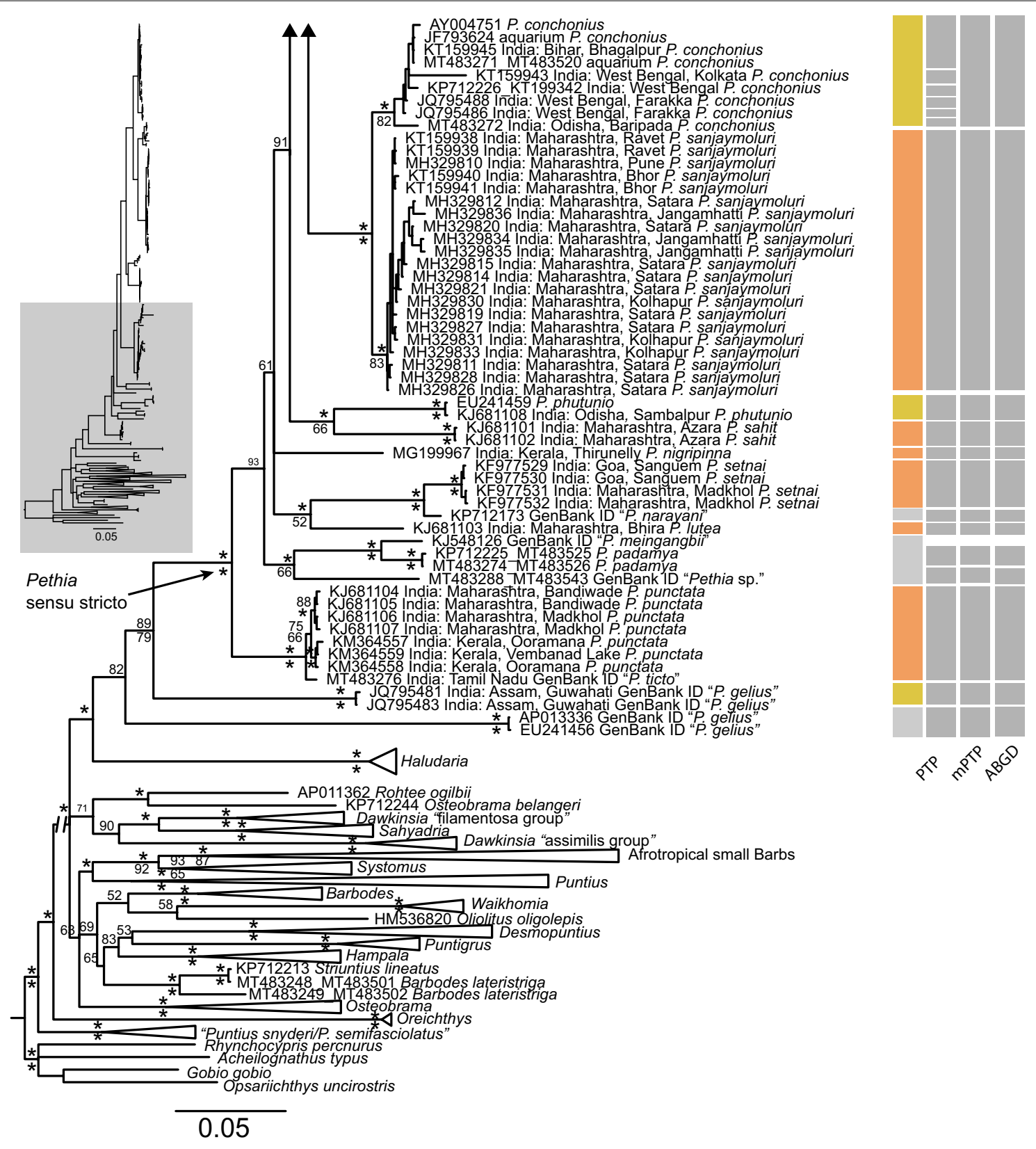

Fig. 4 continued

of Pethia melanomaculata, with strong node support (Additional file 1: Fig. S2).

A clade comprising $P$. longicauda and $P$. pookodensis from peninsular India, and P. ticto sensu stricto from North India, is recovered as the sister group of the clade that includes the Sri Lankan P. reval and $P$. cumingii in the concatenated and $c y t b$ phylogenies, with strong node support (Fig. 4, Additional file 1: S1). In the rag1 phylogeny, a clade comprising of GenBank sequences identified as "P. phutunio" (=P. longicauda), "P. stoliczkana"
(=P. ticto), or "P. ticto" is recovered as the sister group of the clade that includes the Sri Lankan $P$. reval and $P$. cumingii, with strong node support (Additional file 1 : Fig. S2). Pethia cumingii and P. reval are not recovered as reciprocally monophyletic. Four subclades which, for brevity, we name A, B, C, and $\mathrm{D}$, are recognized within $P$. cumingii and $P$. reval in the concatenated and cytb phylogenies, with strong node support (Fig. 4, Additional file 1: Figs. S1, S2). Among these four subclades, A and $\mathrm{B}$ are representative of $P$. reval, while $\mathrm{C}$ and $\mathrm{D}$ are mostly 

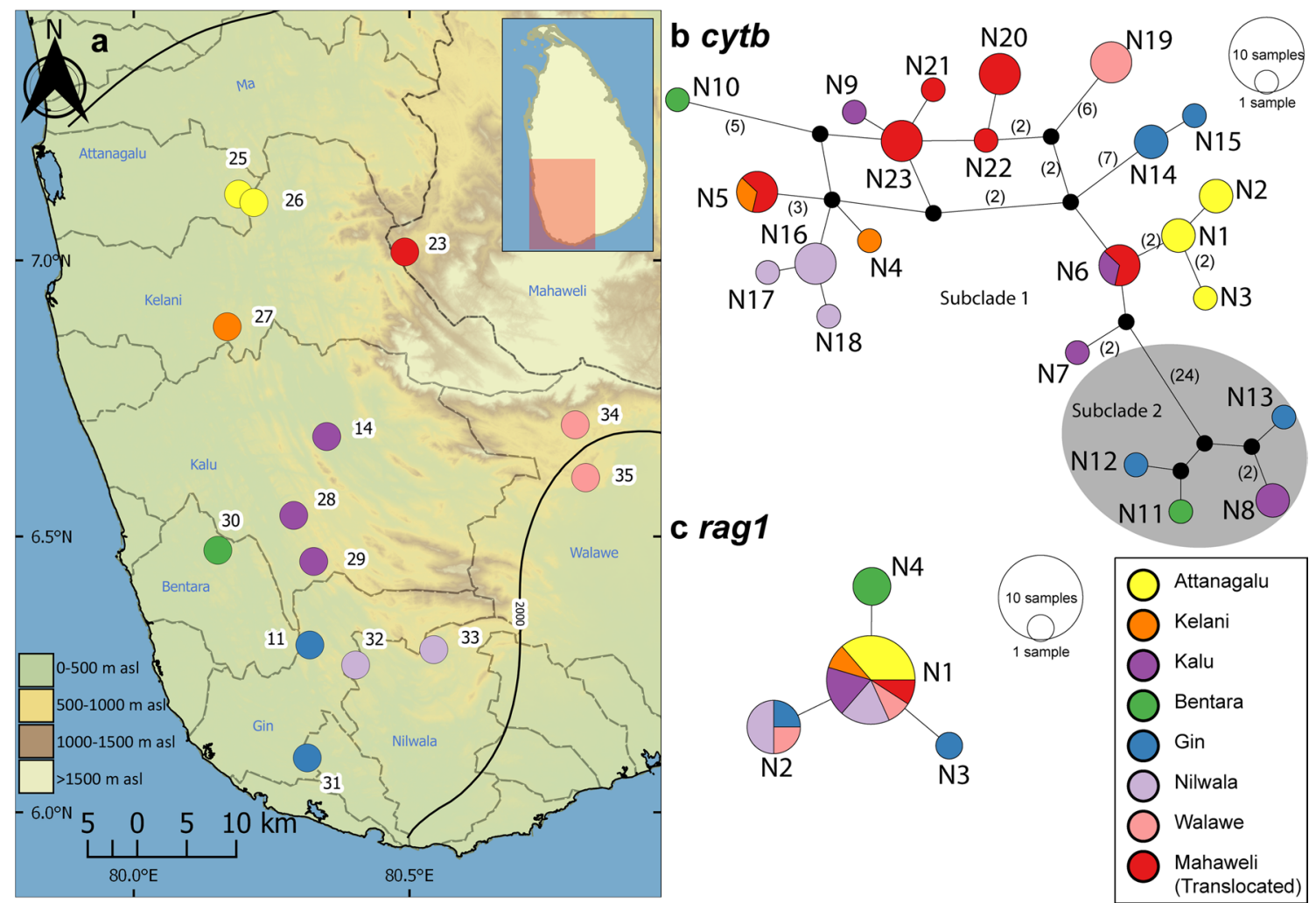

Fig. 5 a Sampling localities for Pethia nigrofasciata for the molecular analysis in the present study. Numbers on the map represent the sampling localities listed in Table 1. Median-joining haplotype network for P. nigrofasciata, based on the analysis of $\mathbf{b}$ a 1082 bp fragment of the cytb gene, and $\mathbf{c}$ a $1490 \mathrm{bp}$ fragment of the rag 1 gene. The number of mutational steps $>1$ is indicated in parentheses. The black circles are hypothetical nodes. Legend colours correspond to river basins

representative of $P$. cumingii, based on the geographic distribution and coloration of the specimens sequenced. Subclade A consists of $P$. reval originating from the Attanagalu, Ma and Deduru basins, while subclade B consists of $P$. reval originating from the Kelani basin. The translocated populations of $P$. reval in the Mahaweli are represented in both subclades A and B. Subclade C includes $P$. cumingii originating from the Bentara and Gin basins and P. reval from the Attanagalu basin (Fig. 4, Additional file 1: Fig. S1). Subclade D includes P. cumingii originating from the Kalu basin. Such geographic structure in populations of $P$. reval and $P$. cumingii is not evident from the rag1 phylogeny (Additional file 1: Fig. S2).

In the cytb and the concatenated phylogeny, the clade that includes Pethia nigrofasciata and P. bandula is recovered, with strong node support, as the sister group of the clade that includes $P$. cumingii, $P$. reval, P. ticto, P. longicauda and P. pookodensis (Fig. 4, Additional file 1: Fig. S1). Within P. nigrofasciata, two subclades are recovered in the concatenated and the cytb phylogenies (subclades 1 and 2; Fig. 4, Additional file 1: Fig. S1). Subclade 1 is a widespread lineage represented by samples from the Attanagalu, Kelani, Kalu, Bentara, Gin, Nilwala and Walawe basins. Subclade 2 is a lineage represented by samples from the Kalu, Bentara and Gin basins. The samples DZ3096 and DZ3095 sequenced from Horawala in the Bentara basin belong to subclades 1 and 2 , respectively. The remaining locations from which $P$. nigrofasciata have been sequenced are not shared between these two subclades (Fig. 4, Additional file 1: Fig. S1). All the populations of P. nigrofasciata translocated to the Mahaweli basin belong to subclade 1. In the rag1 phylogeny, these two subclades are not apparent in $P$. nigrofasciata (Additional file 1: Fig. S2). The phylogenetic relationships of P. bandula are not clearly resolved: it is clustered within subclade 1 of $P$. nigrofasciata (Fig. 4, Additional file 1: Fig. S1).

\section{Molecular species delimitation}

The number of species delimited in PTP, MPTP and ABGD were mostly congruent (Fig. 4). The MCMC analyses for both PTP and MPTP reached convergence based 

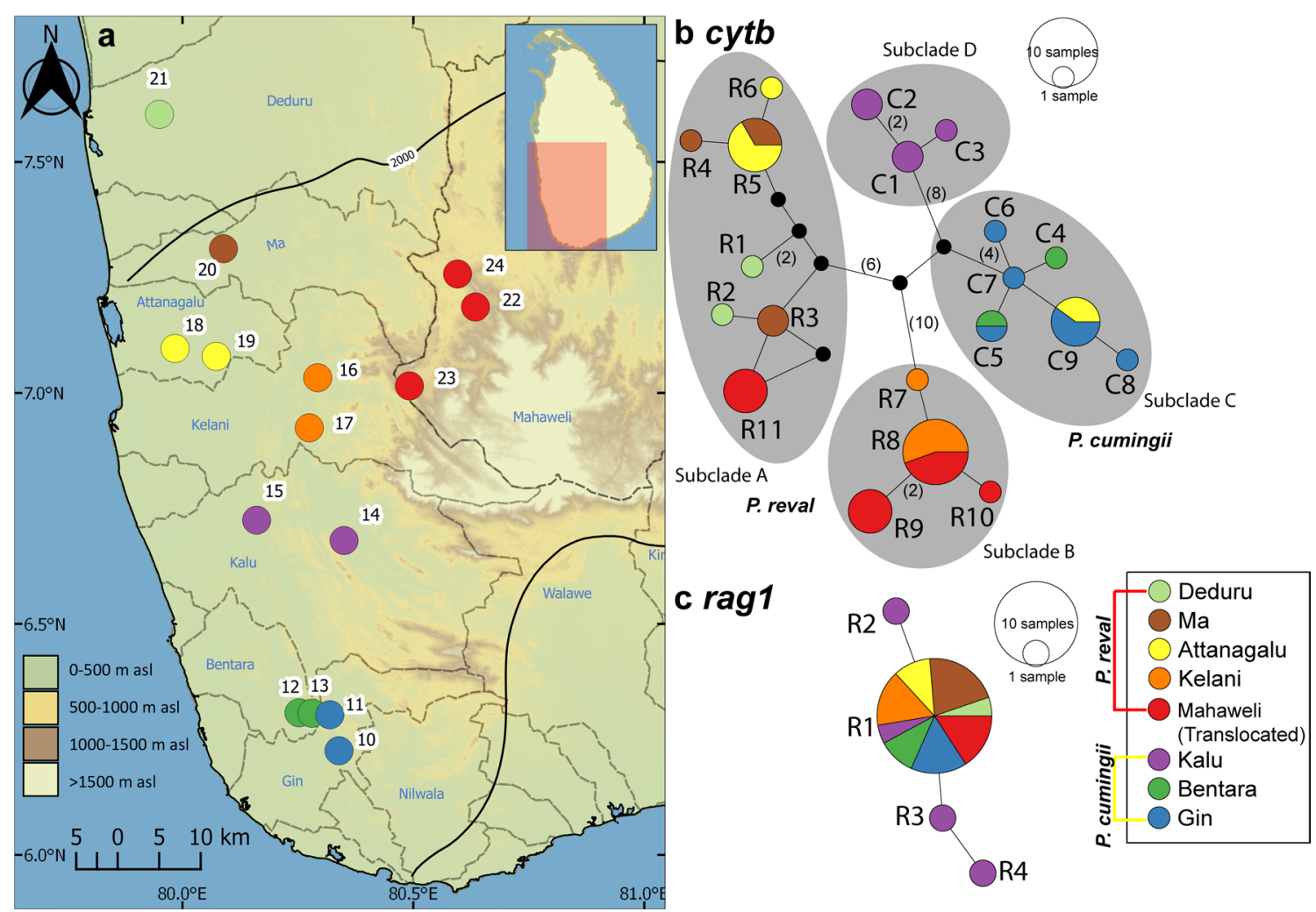

Fig. 6 a Sampling localities for Pethia cumingii and P. reval for the molecular analysis in the present study. Numbers on the map represent the sampling localities listed in Table 1. Median-joining haplotype network for Pethia cumingii and P. reval, based on the analysis of $\mathbf{b}$ a 1082 bp fragment of the cytb gene, and c a $1490 \mathrm{bp}$ fragment of the rag 1 gene. The number of mutational steps $>1$ is indicated in parentheses. The black circles are hypothetical nodes. Legend colours correspond to river basins

on the plots of generation vs. likelihood score. For the 145-taxon dataset for $c y t b$, the mPTP and the PTP analyses delimited 18 and 25 species, respectively (Fig. 4). In both analyses, the posterior support from the MCMC analyses for most species delimited was 1.0. The main difference between the outcomes of these two analyses was that in the PTP analysis, the clade that included $P$. conchonius was unrealistically delimited as six species, whereas the MPTP analysis delimited this clade as a single species (Fig. 4). In the ABGD analysis, at a minimum gap width of $1.5,1.0$ or 0.8 and a p-value of $\sim 0.01$, the initial partition of the p-distance, and JC69 models, inferred 17 species while the K80 model inferred 14 species.

The subclades 1 and 2 of P. nigrofasciata were delimited as two species in the PTP and MPTP analysis, while ABGD delimited these as a single species. Pethia bandula, which is not resolved in the molecular phylogeny, was delimited as conspecific with $P$. nigrofasciata (Fig. 4). Pethia cumingii and P. reval were delimited as a single species in all three analyses, while Pethia melanomaculata too, was delimited as a single species in all three analyses. Among the Indian taxa, most valid species were correctly delimited. The most notable exception was the clade that includes $P$. ticto, $P$. longicauda and $P$. pookodensis. All three molecular species-delimitation methods failed to delimit ticto and P. longicauda, while P. pookodensis was delimited only in the PTP analysis (Fig. 4).

The uncorrected pairwise $c y t b$ genetic distances for Sri Lankan species of Pethia are given in Additional file 1: Table S5. The smallest maximum intraspecific genetic distance in $c y t b$ among these species is $0.6 \%$, in P. melanomaculata, while the greatest is $4.0 \%$, between subclades 1 and 2 in P. nigrofasciata. Pethia melanomaculata differs from the members of the clade that is recovered as its sister group in the concatenated phylogeny by an uncorrected pairwise $c y t b$ distance of 4.4-6.4\%, while $P$. cumingii and $P$. reval differ from their sister group, which includes $P$. ticto, $P$. longicauda and $P$. pookodensis, by 4.7-6.9\%. 

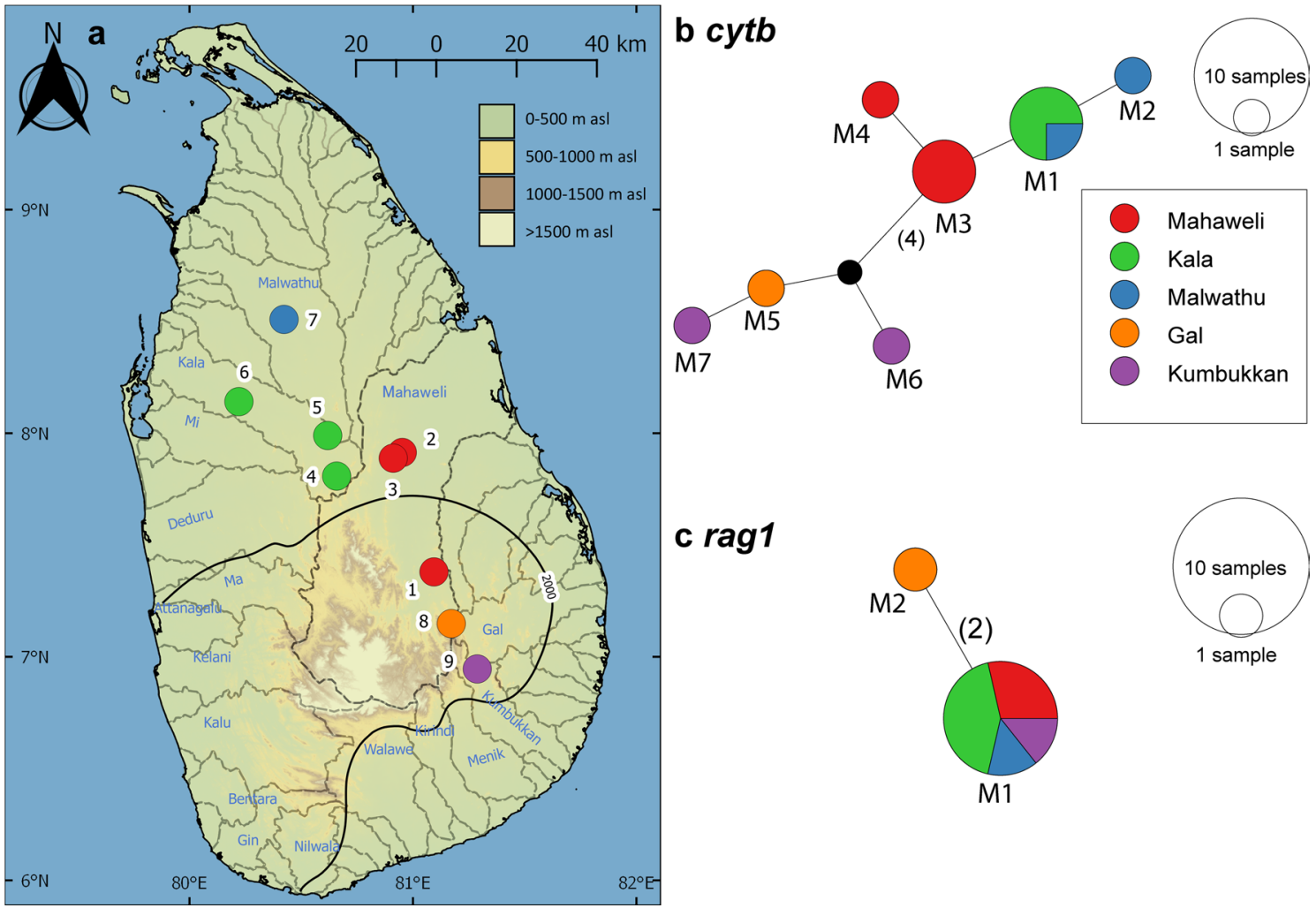

Fig. 7 a Sampling localities for Pethia melanomaculata for the molecular analysis in the present study. Numbers on the map represent the sampling localities listed in Table 1. Median-joining haplotype network for P. melanomaculata, based on the analysis of (b) a 1082 bp fragment of the cytb gene, and c a 1490 bp fragment of the ragl gene. The number of mutational steps $>1$ is indicated in parentheses. The black circles are hypothetical nodes. Legend colours correspond to river basins

\section{Genetic diversity and phylogeography}

For each gene marker ( $c y t b$ and rag1), the number of haplotypes, polymorphic sites, parsimony-informative sites, and nucleotide and haplotype diversities, are given in Additional file 1: Table S6 for P. cumingii, P. melanomaculata, P. nigrofasciata, and $P$. reval. Overall, the nucleotide and haplotype diversities among the wet zone species $(P$. nigrofasciata, $P$. cumingii and $P$. reval) were greater compared to those of the dry zone species, $P$. melanomaculata. None of the neutrality tests were significant for any of these four species (Additional file 1: Table S6).

In the $c y t b$ haplotype network for P. nigrofasciata, only two haplotypes (N5 and N6) are shared between basins, while the remainder are confined to individual basins (Fig. 5b). The haplotypes N5 and N6 occur in translocated populations of $P$. nigrofasciata in the Mahaweli basin; these haplotypes are shared with the Kelani and Kalu basins, respectively. Four more haplotypes N20-N23 from the translocated populations in the Mahaweli basin form unique haplotypes. While most haplotypes are confined to individual basins, they do not show a clear phylogeographic structure in the median-joining haplotype network. Subclade 2 of $P$. nigrofasciata is separated from subclade 1 by a minimum of 27 mutation steps. The rag 1 median-joining haplotype network for P. nigrofasciata exhibits a star-like pattern in which $\mathrm{N} 1$, a high-frequency

(See figure on next page.)

Fig. 8 Multivariate analysis of morphometric data for the Sri Lankan species of Pethia. a PCA biplot of factor scores and factor loadings for $P$. bandula, P. nigrofasciata, P. cumingii, P. reval, and P. melanomaculata. b PCA biplot of factor scores and factor loadings for P. bandula, P. nigrofasciata (excluding Attanagalu population), and P. cf. nigrofasciata (Attanagalu population). c PCA biplot of factor scores and factor loadings for $P$. reval, $P$. cumingii (excluding Kalu population), and P. cf. cumingii (Kalu population). $\mathbf{d}$ MCA biplot of factor scores and factor loadings for meristic data in $P$. bandula, P. nigrofasciata (excluding Attanagalu population), P. cf. nigrofasciata (Attanagalu population), P. cumingii (excluding Kalu population), P. cf. cumingii (Kalu population), P. reval, and P. melanomaculata. Ellipses delineate $95 \%$ confidence intervals 


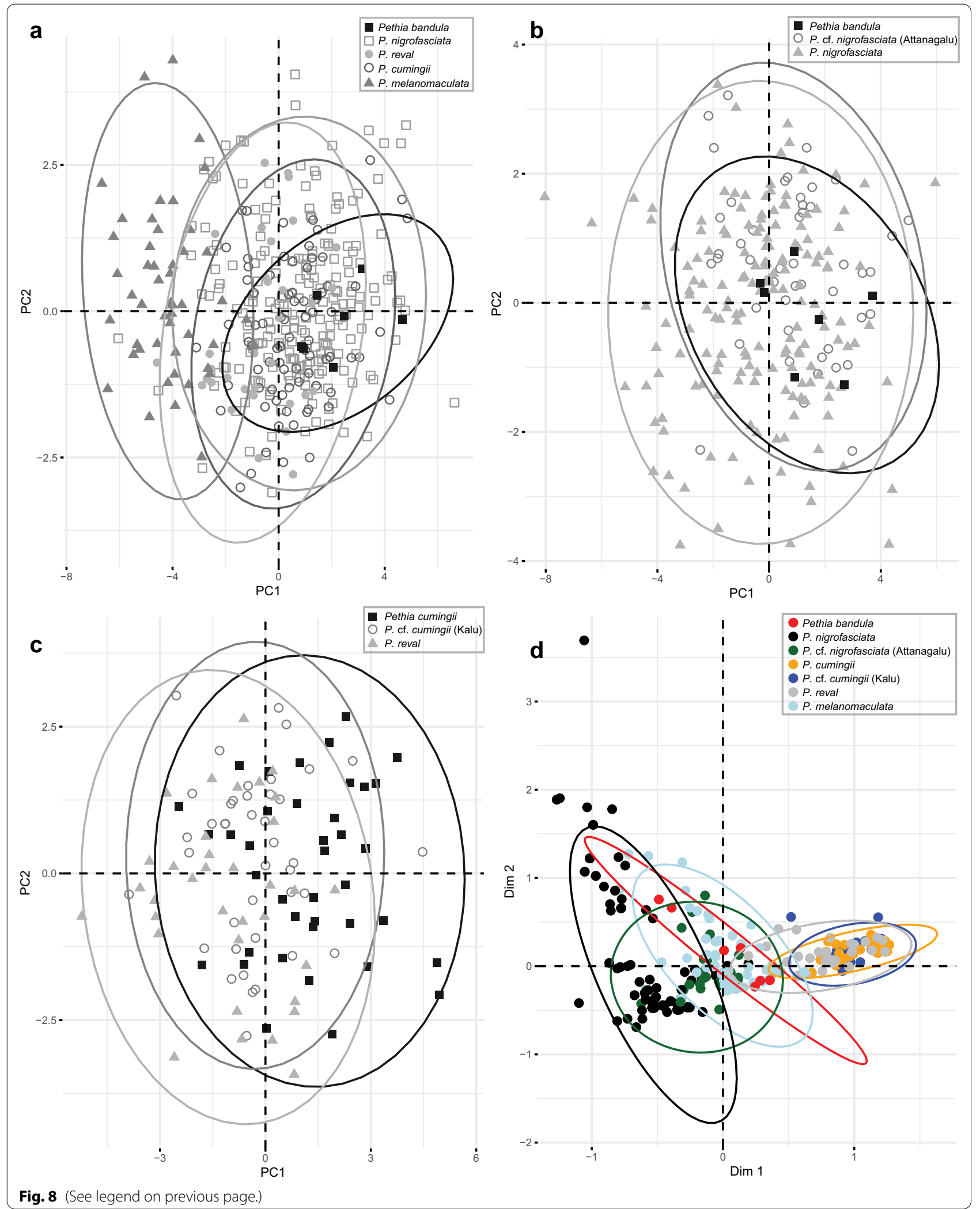




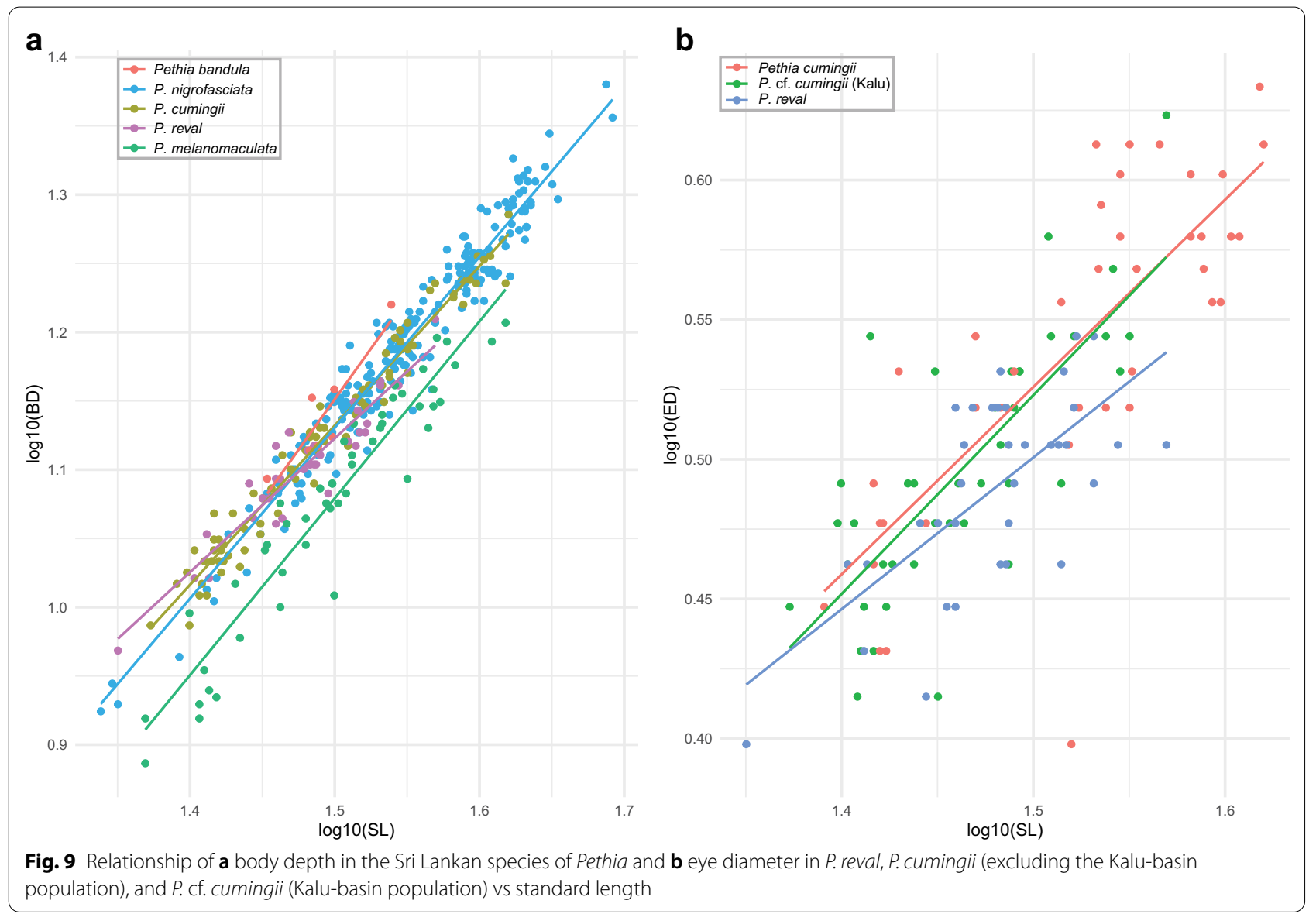

haplotype, is surrounded by low-frequency haplotypes, each separated from $\mathrm{N} 1$ by a single mutational step (Fig. 5c).

In the $c y t b$ haplotype network for $P$. cumingii and $P$. reval, the four subclades are separated from each other by a minimum of 12 mutational steps (Fig. 6b). Only four haplotypes (R5, R8, C5 and C9) are shared between basins; the rest are confined to the individual basins (Fig. 6b). Haplotype R5 is shared between a pair of adjacent basins, the Ma and Attanagalu, while haplotype R8 is shared between the Kelani and the translocated populations of P. reval in the Mahaweli basin. Haplotype C5 is shared between the two adjacent basins, Bentara and Gin, while C9 is the only shared haplotype between $P$. cumingii (from the Gin basin) and $P$. reval (from the Attanagalu basin). Three other haplotypes, R9-R10 and R11 identified in the translocated populations in the Mahaweli basin, form unique haplotypes within subclades B and A, respectively (Fig. 6b). There is some phylogeographic structure in $P$. cumingii and $P$. reval, which is also reflected in the four subclades. Excluding the populations translocated to the Mahaweli, in subclade A, $P$. reval is represented in samples from the Deduru, $\mathrm{Ma}$, and Attanagalu basins, while in subclade B, it is represented in samples from the Kelani basin. Subclade D contains only samples from the Kalu basin, while in subclade C, except for $\mathrm{C} 9$, the remaining haplotypes are confined to the southern Bentara and Gin basins (Fig. 6b). The rag1 median-joining haplotype network for P. cumingii and $P$. reval exhibit a high-frequency haplotype, R1, found in both $P$. cumingii and $P$. reval from all the sampled river basins, in addition to three haplotypes, R2-R4, unique to the Kalu basin (Fig. 6c).

In the $c y t b$ haplotype network for P. melanomaculata, only a single haplotype, M1, is shared between two adjacent basins: Kala and Malwathu, in the northern dry zone. The rest are confined to individual basins (Fig. 7b). The haplotypes from the eastern basins Gal (M5) and Kumbukkan (M6 and M7) are separated from those of the Mahaweli and northern dry zone basins by a minimum of five mutational steps (Fig. 7b). The rag1 haplotype network for P. melanomaculata contains only two haplotypes, $\mathrm{M} 1$ and $\mathrm{M} 2$, in which $\mathrm{M} 1$ is a high-frequency haplotype, while M2 is confined to the Gal basin (Fig. 7c). 


\section{Morphometry, meristics and statistical analysis}

In the size corrected PCA of morphometric measurements of the five species of Pethia represented in Sri Lanka, PC1 and $\mathrm{PC} 2$ explain $41.5 \%$ of the total variance (Fig. 8a). In this PCA, PC1 is explained mostly by body depth and interorbital width, while PC2 is explained mostly by postdorsal length and prepelvic length (Additional file 1: Table S7). Pethia bandula, P. nigrofasciata, $P$. cumingii, and $P$. reval show almost complete overlap in the morphospace, while $P$. melanomaculata shows a separation from the preceding four species (Fig. 8a). The relationship between body depth and standard length in these five species is illustrated in Fig. 9a. Pethia melanomaculata has a lesser body depth $(32.3-42.2 \% \mathrm{SL}$, mean $=38.0)$ compared with $P$. bandula $(42.2-48.0 \% \mathrm{SL}$, mean $=44.5)$, $P$. nigrofasciata $(37.2-50.5 \% \mathrm{SL}$, mean $=44.0)$, P. cumingii $(38.6-46.4 \% \mathrm{SL}$, mean $=42.8)$, and $P$. reval $(38.7-45.6 \% \mathrm{SL}$, mean $=42.0)$. Similarly, $P$. melanomaculata also has a lesser head depth $(19.5-23.9 \%$ SL, mean $=21.9)$ compared with $P$. bandula $(23.1-26.1 \% \mathrm{SL}$, mean $=24.6)$, . nigrofasciata $(21.1-26.6 \%$ $\mathrm{SL}$, mean $=23.6)$, $P$. cumingii $(21.4-26.9 \% \mathrm{SL}$, mean $=23.7)$, and P. reval $(21.1-25.2 \% \mathrm{SL}$, mean $=23.4)$. The other measurements mostly overlap among the five species (Additional file 1: Table S8).

The populations of P. nigrofasciata from the headwaters of the Attanagalu basin proximal to the type locality of $P$. bandula show a mix of meristic characters and intermediate color patterns between $P$. nigrofasciata and P. bandula (Fig. 1g-n, Additional file 1: Table S9). The specimens in the type series of P. bandula $(\mathrm{n}=7)$ possess an incomplete lateral line with 7 (2), 8 (1), 9 (3), or 10 (1) pored scales in the lateral-line series (Fig. 1d-f). Except for a single specimen, the series of $P$. nigrofasciata $(\mathrm{n}=167)$ examined from all the river basins excluding Attanagalu possess a complete lateral line, with 17 (1), 18 (9), 19 (62), 20 (64), 21 (23), or 22 (7) pored scales (Fig. 1p-r). In contrast, 30 specimens from populations of $P$. nigrofasciata in the headwaters of the Attanagalu basin possessed an incomplete lateral line, with 6 (5), 7 (2), 8 (6), 9 (3), 10 (2), 11 (4), 12 (3), 13 (2), 15 (1), or 16 (2) pored lateral-line scales (Fig. 1i-l), while a further 17 possess a complete lateral line with 19 (6), 20 (9), or 21 (2) pored scales (Fig. 1g, h, m, n, Additional file 1: Table S9). The color pattern of P. bandula includes two bars: one on the humeral-cleithral region, and another at the base of the caudal peduncle, whereas in P. nigrofasciata, in addition to the above bars, there is a further, wider bar beneath the dorsal-fin base. However, among the populations of $P$. nigrofasciata from the Attanagalu basin, in 19 specimens, the wide bar beneath the dorsal fin was incomplete (Fig. 1h-j), or absent (Fig. 1g), while in the remaining 28 specimens it was complete (Fig. $1 \mathrm{k}-$ $\mathrm{n})$. In the size corrected PCA of the morphometric measurements of $P$. bandula, P. nigrofasciata (excluding Attanagalu populations), and $P$. cf. nigrofasciata (Attanagalu population) did not show a clear separation in morphospace (Fig. 8b): the three groups overlapped one another (Additional file 1: Table S10).

Pethia reval from the Kelani to the Deduru basins possess red dorsal, pelvic, and anal fins (Fig. 2b), while in $P$. cumingii from the Bentara and Gin, these fins are yellow (Fig. 2f). However, in populations of $P$. cumingii from the Kalu basin, the dorsal, pelvic, and anal fins are orange (Fig. 2d). Ref. [28] hypothesized that the Kalu basin may have been a zone of hybridization between red-finned $P$. reval and yellow-finned $P$. cumingii. To test whether these three groups (i.e., P. reval, the Bentara and Gin populations of $P$. cumingii, and the Kalu population of $P$. cf. cumingii), separate in the morphospace, we carried out a size-corrected PCA of morphometric measurements, which showed almost a complete overlap among the three groups (Fig. 8c). The relationship between eye diameter and standard length, which was identified by Meegaskumbura et al. [28] to be of value in distinguishing between $P$. reval (present study: eye diameter 8.6$11.5 \% \mathrm{SL}$, mean $=10.3$ ) and $P$. cumingii (present study: $7.6-12.6 \% \mathrm{SL}$, mean $=10.5$ ), remains generally consistent when a large series of specimens is considered, although with a greater variation (Fig. 9b). In $P$. cf. cumingii, the relationship between eye diameter and standard length (present study: $9.2-13.5 \% \mathrm{SL}$, mean $=10.8$ ) is similar to that of $P$. cumingii. The remaining measurements show a broad overlap among these three groups (Additional file 1: Table S11).

In the MCA for the meristic data, the first and second dimensions explain $13.9 \%$ of the total variance (Fig. $8 \mathrm{~d}$ ). In this MCA, the first dimension is explained mostly by the condition of the lateral line (complete or incomplete), the number of scales between the lateral line and dorsalfin origin, and the number of circumpeduncular scales, while the second dimension is explained mostly by the number of pored scales in the lateral line and the number of scales along the lateral series. In the MCA, P. reval, $P$. cumingii, and $P$. cf. cumingii form a cluster with almost complete overlap. Pethia bandula, P. nigrofasciata, and $P$. cf. nigrofasciata form another cluster with partial overlap with each other, though separated from $P$. reval, $P$. cumingii, and $P$. cf. cumingii (Fig. 8d). Pethia melanomaculata show overlaps partially with both the aforementioned clusters.

\section{Discussion}

\section{The genus Pethia}

Following the recognition of the genus by Pethiyagoda et al. [16], several studies confirmed the monophyly of Pethia [e.g., 10, 11, 18, 25, 26]. Nevertheless, about half 
of the 43 species included in the genus since 2012 are yet to be represented in a molecular phylogenetic framework. Doubt remains as to the generic placement of several of these. While Pethiyagoda et al. [16] allocated 23 species to the genus, they drew attention to others for which insufficient information was available, upon which to make a generic placement. 'Pethia' narayani, 'P' sharmai, 'P' aurea, 'P'. cania, 'P.' gelius, 'P.' guganio, 'P. castor', and 'P. pollux' are morphologically so distinct from Pethia sensu stricto and other Smiliogastrini that they may warrant placement in different genera $[16,18,19]$. The original description by Hora [36] of 'Pethia' narayani does not mention a serrated last unbranched dorsal-fin ray, which is a synapomorphy in Pethia. Hora [36] mentions only that "The dorsal fin... possesses a feeble and articulated spine which is considerably longer than the head; its free border is slightly concave though rounded at the top." The holotype of 'P.' narayani, illustrated in Hora [36], exhibits three vertical bands on the side of the body. 'Pethia' narayani in fact may belong to the recently described smiliogastrine genus Waikhomia [37]. 'Pethia' sharmai differs from all congeners in having 40 or more scales along the lateral-line row (vs. 30 or less in Pethia sensu stricto: see Additional file 1: Table S1). It superficially resembles 'P'. guganio. 'Pethia' aurea, 'P'. cania and 'P' gelius appear to form a closely related group united by a striking colour pattern, distinguishing the group from Pethia s.s. [38]. In fact, even in our phylogenies, the GenBank sequences identified as "P. gelius" formed a distinct lineage basal to Pethia s.s. (Fig. 4). It seems possible also that ' $P$ '. castor, and ' $P$ '. pollux [18], from Myanmar, may belong to a lineage distinct from Pethia. The phylogenetic relationships of the mentioned Indian and Myanmarese species remain to be explored.

The type species of Pethia, P. nigrofasciata, a Sri Lankan endemic, is included in the present study. Consistent with this, the 36 species we treat as belonging to Pethia s.s. (Additional file 1: Table S1) are characterized by having the following suite of characters: 8 branched dorsalfin rays; 5 branched anal-fin rays; the last unbranched dorsal-fin ray strong, serrated on its posterior margin; 2 or 3 black spots, blotches or bands laterally, including one on the humeral-cleithral region and another above the anal fin or on the caudal peduncle; the lateral line more often incomplete (26 species) than complete (10 species); barbels usually absent (32 species); and 19-30 scales in the lateral-line series. The maximum size for the genus is usually $<50 \mathrm{~mm}$ SL [16]. Most species (perhaps all) are sexually dichromatic. All five species of Pethia in Sri Lanka are consistent with the above conception of the genus.

\section{Phylogeny}

Our taxon sampling includes all five Sri Lankan species of Pethia, sampled from the island's principal rivers, including $c y t b$ sequences derived from reliably identified specimens for $P$. bandula as well as almost all the species reported from South India, to which the Sri Lankan species would be expected to have their closest relationships. This dense sampling adds confidence to the relationships inferred from our phylogenetic analysis.

The concatenated phylogeny confirms our hypothesis that the Sri Lankan representatives of the genus do not form a monophyletic group. This relationship was hypothesized on the basis of four of the five species $(P$. bandula, $P$. nigrofasciata, $P$. cumingii and $P$. reval) exhibiting a similar morphology and being confined to the island's south-western wet and intermediate zones (rainfall $>2.5 \mathrm{~m} / \mathrm{y}$ and $1.8-2.5 \mathrm{~m} / \mathrm{y}$, respectively). The wetzone diversifications of several other cypriniform genera have been shown to be monophyletic [e.g., Systomus: 11, Devario: 14, and Rasbora: 15], whereas such diversifications are rare in the dry zone $[15,39]$. Of the four species of Pethia endemic to the island's south-western wet zone, only one, $P$. reval, has a range extending into the western intermediate zone, as far north as the Deduru basin. Pethia melanomaculata, in contrast, is confined largely to the dry zone, though extending also to the intermediate zone in the east-draining Mahaweli and Gal basins, and the west-draining Deduru basin. It differs from the other four Sri Lankan species of Pethia also in morphology (Figs. 3b-c, 8a, 9a). The sister-group relationship of $P$. melanomaculata is not clearly resolved in our phylogenies (Fig. 4). We suspect this species may have a closer phylogenetic relationship to a lineage from peninsular India that is not represented in our dataset. Similar relationships have been observed for other freshwater fishes widespread in the dry zone of Sri Lanka [40-42] with few exceptions [43].

While our results recover Sri Lankan Pethia as polyphyletic, the four southwestern wet zone species are not recovered as monophyletic, as hypothesized (Fig. 4). The phylogenetic relationship between $P$. nigrofasciata and $P$. bandula is not clearly resolved. Similarly, the relationship between $P$. cumingii and $P$. reval too, is ambiguous. Further, the sister-group of the clade that includes $P$. reval and $P$. cumingii in all the analyses is a well-supported clade that includes several Indian species. The clade that includes Pethia nigrofasciata and P. bandula is recovered as the sister group of the clade that includes $P$. cumingii, P. reval, $P$. ticto, P. longicauda and $P$. pookodensis, with strong node support in all the analyses (Fig. 4, Additional file 1: Figs. S1, S2). Thus, our phylogeny suggests that the 
five species of Sri Lankan Pethia derive from two or three discrete colonization events from the Indian mainland. Multiple colonization events have been recovered also in the case of other freshwater-fish diversifications in Sri Lanka, such as Laubuka, Rasbora, Devario and Systomus [11, 14, 15, 39]. In those cases, the diversifications in the island's wet zone within each genus were shown to stem from a single colonization from India. The present findings support two equally parsimonious scenarios for colonization of Pethia in Sri Lanka. One is that the common ancestors of $P$. melanomaculata, $P$. nigrofasciata and $P$. bandula, and P. cumingii and P. reval derive from three independent colonization events from the Indian mainland. If this scenario is confirmed, then Pethia would be the first freshwater fish genus in which a wet-zone diversification deriving from multiple independent colonization events has been detected in the island. An alternative scenario would be two colonization events from mainland India, being the common ancestors of $P$. melanomaculata and $P$. nigrofasciata, $P$. bandula, $P$. cumingii and $P$. reval, followed by a back-migration to India.

This is noteworthy because, despite having been connected by a broad isthmus during episodes of low sea level, post-Miocene biotic exchanges of forest-adapted taxa between India and Sri Lanka have been infrequent $[5,10,11]$. Though subaerial for most of the Plio-Pleistocene, the Palk Isthmus appears, because it was too arid, to have acted more of a filter than a conduit for the dispersal of forest-adapted taxa $[5,8,10]$. While $P$. nigrofasciata is a rainforest-adapted species, $P$. cumingii and $P$. reval are not obligatory rainforest associates (discussed below). We hypothesize, based on our results, that the common ancestor of $P$. cumingii and $P$. reval was a generalist. In such a scenario, a back migration to India by the common ancestor of $P$. cumingii and $P$. reval through the arid Palk Isthmus or the colonization of the rainforests of the island's wet zone, are both plausible.

\section{Pethia bandula-P. nigrofasciata}

In our $c y t b$ and concatenated rag1 + cytb trees, Pethia bandula renders $P$. nigrofasciata paraphyletic (Fig. 4, Additional file 1: Fig. S2). Pethia bandula is a Critically Endangered species confined to a single localized population in a $\sim 3-\mathrm{km}$ stretch of a small stream within the Kelani basin [29]. It therefore enjoys strict protection, and sampling is not permitted. As such, we were limited to using the 540-552 bp sequences from the $c y t b$ locus available on GenBank, much shorter than the $1082 \mathrm{bp}$ contained in the $c y t b$ sequences newly generated in this study. This may have led to a weakening of the phylogenetic signal represented by $P$. bandula.

It is also possible that $P$. bandula is the result of a recent speciation event. Its range lies at the northern extremity of that of P. nigrofasciata (Fig. 1b). If P. bandula is an incipient species, it could be that the lineages are as yet incompletely sorted or even introgressed, leading to it and $P$. nigrofasciata not being recovered as reciprocally monophyletic based on the genetic markers used in the present study. The observation of mixed morphology in some populations of $P$. nigrofasciata in the headwaters of the Attanagalu basin proximal to the type locality of $P$. bandula appear consistent with such a hypothesis (Fig. 1g-n, Additional file 1: Table S9). Despite all three molecular species-delimitation methods we applied (PTP, $\mathrm{mPTP}$ and ABGD) grouping them as a single species, $P$. bandula and $P$. nigrofasciata are easily distinguished on morphological criteria alone [29]. A genomic approach may reveal clearer structuring and genetic differentiation between the two species, while also revealing evidence of incomplete lineage sorting or hybridization [44-47].

\section{Pethia cumingii-P. reval}

The phylogenetic relationship between $P$, reval and $P$. cumingii too, is not clearly resolved in our concatenated phylogeny (Fig. 4), with all three molecular speciesdelimitation methods recovering them as a single species. Nevertheless, $P$. reval and $P$. cumingii are easily distinguished by the red and yellow, respectively, of their fins, in addition to a suite of morphological characters [28]. There is also a clear geographical signal in the phenotypes of the two species (Fig. 2). The red-finned populations occur exclusively in the northern Deduru, Ma, Attanagalu and Kelani basins, whereas yellow-finned populations occur exclusively in the more southerly Bentara and Gin basins. The Kalu basin lies between the northern and southern watersheds that host exclusively the red or yellow-finned populations assigned the names $P$. reval and P. cumingii, respectively. While populations in the Kalu usually have yellow fins, individuals with a mix of red and yellow or orange fins occur in some localities (Fig. 2d). It could be that speciation in these two lineages too, is recent, with as yet incomplete lineage sorting or introgression. Both these species are assessed as Endangered [48], and accurate recognition of the species' taxonomic status is important in conservation management. While our single-locus species-delimitation and the phylogenetic analyses based on $c y t b$ and ragl failed to separate $P$. reval and $P$. cumingii, we adopt a conservative taxonomic approach and retain them as valid species based on their distinct morphology and allopatric distribution. Similar to the case of $P$. bandula and $P$. nigrofasciata, we expect a genome-wide analysis to recover clear structuring and genetic differentiation between these species while also revealing whether the mentioned phenotypic discrepancies in the Kalu basin are the result of hybridization [28, 44-47]. 


\section{Geographic ranges and habitats}

Pethia nigrofasciata is confined to Sri Lanka's wet-zone basins, from the Attanagalu in the north to the Walawe in the south. It occurs in clear-water streams and rivers with gravel or pebble substrates. The habitats of $P$. nigrofasciata resemble those of the other widespread endemic species in the rainforests of the wet zone, such as Devario micronema, Laubuka varuna, Rasbora wilpita and Systomus pleurotaenia [11, 14, 15, 39]. In contrast, P. reval and $P$. cumingii occupy broader ecological niches. While the former occurs close to banks in rivers associated with rainforest habitats, it is encountered also in pools in the lowland floodplains and in streams traversing rice paddies, with substrates of silt or debris. Thus, although the extension of its range as far north as the Deduru basin in the intermediate zone is unsurprising, $P$. reval is among the two endemic freshwater fishes that occur in both the wet zone and the intermediate zone, the other such species being the silurid catfish Ompok argestes [49].

Pethia cumingii, however, is more associated with rainforests, occurring in both shaded streams and rivers. While our samples of this species derive only from the Kalu, Bentara and Gin basins, we have observed it also in the Nilwala and Walawe basins further south. Meanwhile, Pethia bandula is confined to a single small stream at Galapitamada, its type locality, which traverses a ricepaddy landscape. This region was likely occupied by rainforest prior to anthropogenic modification. In contrast, compared to its four wet-zone congeners, $P$. melanomaculata occupies a broad ecological niche in the dry and intermediate zones. It occurs in lotic habitats such as rivers, streams, canals, as well as lentic habitats such as seasonal pools and reservoirs and, unlike the other Sri Lankan species of Pethia, does not appear to be associated with shade or riparian vegetation.

In some rainforest habitats in the Attanagalu and the Kelani basins, $P$. nigrofasciata and $P$. reval occur in syntopy. Similarly, in such habitats in the Kalu, Bentara, Gin, and Nilwala basins, $P$. nigrofasciata and $P$. cumingii occur in syntopy. While we have not encountered $P$. reval and $P$. melanomaculata in syntopy in the intermediate zone, this would be expected [22, 32]. At the type locality of $P$. bandula, no other species of Pethia occurs. However, both $P$. nigrofasciata and $P$. reval occur in nearby streams [22; present study].

\section{Phylogeography}

Several recent studies have explored the phylogeographic structure of cyprinid species confined to Sri Lanka's southwestern wet zone, such as Devario micronema, Laubuka varuna, Rasbora wilpita, and Systomus pleurotaenia [11, 14, 15, 39]. All these rainforest associates show strong within-basin genetic structure, with limited gene flow between even adjacent basins. In these cases, it appears that inter-basin dispersal is inhibited by the concerned species being restricted to shaded clearwater streams draining the foothills of the island's central mountains. They are thus absent from the lowland floodplain, across which there is potentially hydrological connectivity between basins when flooding follows episodes of heavy rainfall. In cases where inter-basin geneflow had in fact occurred, it was inferred that this was the result of headwater river-capture events rather than via the lowland floodplain $[5,11]$.

Pethia nigrofasciata too, shows within-basin phylogeographic structure, with no cytb haplotypes shared between basins (Fig. 5). As mentioned above, our concatenated phylogeny (Fig. 4) recovered $P$. nigrofasciata as two well-supported, sympatric subclades, one spanning the distribution of the species in Sri Lanka, from the Attanagalu to the Walawe basins, and the other confined to the region between the Kalu and Gin basins, inclusive. Such a pattern has not been observed in the other phylogeographic studies of Sri Lankan cyprinids published so far $[5,11,14,15,39]$. Given that our genetic dataset is limited, it is difficult to offer an explanation for this observation. However, in our rag1 nuclear dataset (Additional file 1: Fig. S2), these two subclades are not apparent. It is possible that these lineages underwent secondary admixture between allopatrically evolved populations [50]. The complex topography of the southwestern wet zone may have imposed historical biogeographic barriers to gene flow between the two populations. The $c y t b$ haplotype network of $P$. nigrofasciata too (Fig. 5b), does not suggest inter-basin gene flow through headwater capture between the adjacent basins. The star-like pattern of the rag1 haplotype network of $P$. nigrofasciata (Fig. 5c), however, may suggest a recent range expansion, even though the neutrality tests were not significant. Broader sampling within each river basin and genome-wide data may reveal a clearer picture of the evolutionary history of these two mitochondrial lineages in P. nigrofasciata. While no haplotypes are shared between these two subclades, samples from the same locality may belong to both subclades. For example, the $c y t b$ haplotypes $\mathrm{N} 10$ and $\mathrm{N} 11$ occur in members of subclades 1 and 2, respectively, at the same locality in the Bentara basin. The occurrence of distinct mitochondrial lineages in syntopy has also been observed in the southwestern basins of Sri Lanka for the cyprinid Garra ceylonensis [5]. This further supports our hypothesis that these samples may have derived from two historically separate matrilineal evolutionary lineages.

While $P$. cumingii and $P$. reval are not obligatory rainforest associates, three of the four subclades of this species-pair exhibit distinct phylogeographic structure 
(Fig. 4). Subclades A and B contain haplotypes unique to $P$. reval, and subclade D contains haplotypes unique to $P$. cf. cumingii from the Kalu basin. Subclade C, however, includes haplotypes shared between both $P$. reval and $P$. cumingii. One cytb haplotype, R5, is shared between the adjacent $\mathrm{Ma}$ and Attanagalu basins, while another (C5) is shared between the Bentara and Gin. Haplotype C9, however, is disjunct between the Attanagalu (in P. reval) and Gin (in P. cumingii) basins. It may represent a shared ancestral haplotype which is now fixed in $P$. cumingii. Interestingly, three $c y t b(\mathrm{C} 1-\mathrm{C} 3)$ and three rag1 (R2-R4) haplotypes are unique to the Kalu basin, that shares no haplotypes with any other basin.

The species of Pethia confined to the island's southwestern wet and intermediate zones show evidence of strong phylogeographic structure. Unlike in other endemic cyprinids studied so far, there is little evidence of gene flow between adjacent basins [11, 14, 15, 39]. This could be because the diversification of these lineages has been recent, with ancestral polymorphism retained and lineage sorting as yet incomplete. A genome-wide analysis could provide a clearer understanding of the evolutionary history of these species.

The phylogeographic structure observed in Pethia melanomaculata resembles that in Laubuka lankensis, which too, has a similar distribution, being confined to the dry and intermediates zones [39]. In both these species, three regional haplogroups can be identified: northwest, Mahaweli, and eastern. Only a single $c y t b$ haplotype is shared between rivers: the adjacent Kala and Malwathu basins in the northwest haplogroup. While the remaining haplotypes are unique, they are separated by relatively few mutational steps, in contrast to the condition observed in P. nigrofasciata, P. cumingii, and P. reval.

Most of the dry zone's fishes derive from recent (Pleistocene) dispersants from India, adapted to an arid, strongly seasonal climate [5]. These exhibit little phylogeographic structure $[10,11,14,15,39,41]$. Within the widespread species in the dry zone, the populations from the eastern basins (principally the Gal, Kumbukkan, Menik and Kirindi, which drain the eastern slopes of the central hills) appear to show greater genetic diversity compared with populations in the northwest and the Mahaweli basins. This region lies within the intermediate zone and benefits from higher annual-though less markedly seasonal-rainfall than the northwest and Mahaweli dry zone. It has two endemics confined to it: Rasbora adisi and Laubuka hema [15, 39]. As P. melanomaculata too, demonstrates, the eastern basins show substantial isolation from their neighbours. The region has until now not attracted attention as a focus for conservation, but clearly warrants such consideration.
Nevertheless, perhaps owing to the wet zone's greater topographic complexity [51], and despite its extent being only about a quarter that of the dry zone, nucleotide and haplotype diversity in the wet-zone endemics $P$. nigrofasciata, $P$. cumingii and $P$. reval are greater than in $P$. melanomaculata. This phenomenon has been observed previously in species pairs in which one is confined to the wet zone while the other is distributed across the dry zone, such as Devario micronema vs D. malabaricus, Laubuka varuna vs. L. lankensis, Systomus pleurotaenia vs $S$. sarana, and Rasbora wilpita vs $R$. dandia $[11,14,15$, 39]. As Potter et al. [52] show, genetic diversity in low-dispersal vertebrate species tends to be higher in mesic, topographically complex biomes, compared to that of species inhabiting dry and topographically less complex biomes.

\section{Translocations}

The haplotype networks of both $P$. nigrofasciata and P. reval indicate shared mitochondrial haplotypes (N5 and R8, respectively) between the west-draining Kelani and east-draining Mahaweli basins. These basins share a common boundary along a $40 \mathrm{~km}$ long, 600-2000-m high ridge that extends from Ginigathena to the Horton Plains. Sudasinghe et al. [53] reported a shared haplotype between populations of the dwarf snakehead Channa orientalis between the two basins, suggesting that gene flow between them is possible. In the case of Pethia, however, Wikramanayake [34] recorded a translocation experiment in which both $P$. nigrofasciata and $P$. reval (which he referred to as Puntius cumingii) were introduced to a stream near Ginigathena $\left(6.987^{\circ} \mathrm{N}, 80.499^{\circ} \mathrm{E}\right)$. Whether stemming from this introduction or other undocumented ones [see: 32], both $P$. nigrofasciata and $P$. reval now occur as far as $40 \mathrm{~km}$ downstream, at Peradeniya.

Wikramanayake [34] reported the stocks of $P$. reval and P. nigrofasciata introduced to the Mahaweli in 1981 to have come from the Kelani and Kalu basins, respectively. He was not, however, associated with the original translocation experiment and based his report on information from secondary sources. Sudasinghe et al. [33] showed that the stock of Rasboroides pallidus translocated in this experiment originated not from the Kalu, as reported by Wikramanayake [34], but likely from the Bentara basin. In the present study, we show the populations of Pethia introduced to Mahaweli derive from multiple sources. The Mahaweli populations of $P$. reval contain haplotypes belonging to both subclade A (native to the Deduru, Ma and Attanagalu basins) and subclade B (native to the Kelani). Similarly, the Mahaweli populations of $P$. nigrofasciata contain haplotypes otherwise unique to the Kelani and Kalu basins, in addition to several unique haplotypes, all within the subclade 1 of native $P$. nigrofasciata. In both species, the multiple unique haplotypes in 
the Mahaweli (R9-R11 in P. reval, N20-N23 in P. nigrofasciata) suggest that our sampling density underrepresents the haplotype diversity of their native populations.

Deraniyagala [32] reported $P$. reval (as Puntius cumingii) from Peradeniya, which suggests that a translocation occurred even before that reported by Wikramanayake [34]. It is also possible that populations of both $P$. reval and $P$. nigrofasciata may have escaped from the fisheries station at Ginigathena, and perhaps also from Peradeniya University, both on the Mahaweli River [54, 55]. The populations of both these fishes in the Mahaweli may thus result from independent founder events spanning several decades, a scenario consistent with our results. This is unsurprising in the light of both species having been popular in the ornamental fish trade for almost a century now.

\section{Conclusions}

Despite Pethia being a widespread freshwater fish genus in South Asia, most studies so far have focused on taxonomy, with little or no emphasis on geographic sampling focusing on phylogeographic work. We focus on phylogeny, phylogeography, using nuclear DNA and mitochondrial DNA markers, and compare these results with morphology of the group. Polyphyly in Sri Lankan Pethia suggests two or three colonizations from mainland India. Strong phylogeographic structure suggests that the topographically complex wet zone harbors greater genetic diversity than the more uniform dry-zone. Mixed morphological characters between some of the taxa, and their unresolved phylogenies, may suggest recent speciation events with incomplete lineage sorting, or hybridization. The knowledge generated will not only form a foundation for systematics work, but also will help in understanding the processes of speciation and patterns of distribution, allowing for informed conservation of this charismatic group of fishes.

\section{Methods DNA protocols}

Gene nomenclature follows ZFIN Zebrafish Nomenclature Conventions (https://goo.gl/MdawKQ). The following new marker sequences were generated for all the Sri Lankan species of Pethia except P. bandula: 99 mitochondrial cytochrome $b$ (cytb) and 48 nuclear recombination activating protein 1 (rag1) from 35 locations representative of 14 major river basins in Sri Lanka (Table 1, Figs. 1a, 2a, 3a). Owing to it being Critically Endangered, we lacked permission to obtain fresh samples of $P$. bandula. For this species, therefore, $c y t b$ sequences based on reliably identified specimens $[1,16,28]$ were obtained from GenBank. Methods of DNA extraction, PCR amplification and PCR product purification for $c y t b$ and rag1 follow Sudasinghe et al. [4] and Sudasinghe et al. [14], respectively. ChromasPro v1.34 (Technelysium Pty Ltd, Australia) and MEGA v. 7.0 [56] were used to verify the newly generated sequences and to make consensus sequences of the $5^{\prime}$ and $3^{\prime}$ strands, respectively.

The comparative genetic dataset representative of Smiliogastrinae based on Sudasinghe et al. [11], together with additional sequences generated by Katwate et al. [57], Katwate et al. [37], Ren et al. [25] and Sudasinghe et al. [10], were compiled and used in the present study (Additional file 1: Table S2). Among the 16 valid species of Pethia from Sri Lanka and peninsular India, 13 are represented in our $c y t b$ dataset, based on reliably identified specimens [present study; 16, 19, 23, 24, 28, 30, 31, 58]. This reference dataset thus allowed us to confidently identify some incorrectly identified or dubious GenBank sequences. The only three species of Pethia from the Indian peninsula not represented in our dataset are $P$. narayani, $P$. sharmai and $P$. striata. Of these, the generic placement of the first two is doubtful [see Discussion; also 16,19]. Unfortunately, we lack a nuclear (rag1) reference dataset, based on reliably identified specimens, of Indian Pethia. The available rag1 sequences in GenBank are in any case scarce compared with $c y t b$. Some of the available rag1 sequences, however, are accompanied by $c y t b$ sequences derived from the same voucher specimens [e.g., 25]. This allowed us to infer the identification of these rag1 sequences from their $c y t b$ counterparts. In cases where the GenBank identification is doubtful, however, we place the species name within double quotes.

The $c y t b$ and rag1 sequences were aligned independently, using ClustalW in MEGA v. 7.0 [56] and each alignment checked and translated to verify the absence of frameshift mutations and premature stop codons. The online program FaBox [59] was used to condense the sequences into unique haplotypes. PhyloSuite v1.2.1 was used in data concatenation and conversion of sequence formats [60].

\section{Phylogenetic analysis}

For each single gene dataset of $c y t b$ (1082 bp, 395 taxa) and rag1 (1490 bp, 204 taxa), and for the concatenated dataset of $c y t b+$ rag1 (2572 bp, 371 taxa), phylogenetic inferences based on Maximum Likelihood (ML) and Bayesian inference (BI) were made using RAxML-NG [61] and MrBayes v3.2 [62] through the CIPRES Science Gateway [63].

The optimal nucleotide substitution model and partitioning schemes for the BI analysis were evaluated using PartitionFinder 2 [64] through the CIPRES Science Gateway. Each codon position of each gene was given as the starting subset, branch lengths as "linked", model as MrBayes, model selection under the Bayesian information criterion (BIC), and search method as the "greedy" 
algorithm [65]. These were then evaluated using PhyML 3.0 [66] in the PartitionFinder 2 package. Four Metropolis coupled Markov-chain Monte Carlo (MCMCMC) chains in two independent runs of 10 million generations, with a sampling interval of 1000 each, were conducted in MrBayes v3.2 for the BI analysis. Convergence of the two runs was checked using Tracer [67] and the burn-in fraction set as 0.1. Statistical support for the nodes in the BI analyses was determined using the trees which remained after burn-in, based on the Bayesian posterior probabilities (PP) of the clades [68].

ModelTest-NG [69] through the CIPRES Science Gateway was used to determine the optimal nucleotide substitution model for the ML inference, using the minimum AIC score. Statistical support for the nodes in the ML inference was determined by Felsenstein's bootstrap method for 1000 replicates. The trees obtained from BI and ML analyses were visualized using Figtree v1.4.3 (http://tree.bio.ed.ac.uk/software/figtree). The different partitioning schemes, evolutionary models and number of sequences used in the analyses are provided in Additional file 1: Table S3.

\section{Molecular species delimitation}

Molecular species delimitation for single-locus data includes several tree-based and distance-based methods [70-75]. Use of a combination of these approaches is increasingly applied to overcome the weaknesses of individual methods [76-79]. We used three different singlelocus molecular species-delimitation algorithms to infer the species boundaries in our dataset: the distance-based Automatic Barcode Gap Discovery (ABGD) [73], the tree-based multi-rate Poisson Tree Processes (mPTP) [71], and the Poisson Tree Processes (PTP) [75].

The ABGD analysis was run using the Unix commandline version available from https://bioinfo.mnhn.fr/abi/ public/abgd/. The entire dataset of $c y t b$ for Pethia was run in ABGD under the JC69, K80 and uncorrected $\mathrm{p}$-distance models while varying the minimum gap width (X) as $\mathrm{X}=1.5, \mathrm{X}=1.0$ and $\mathrm{X}=0.8$. The rest of the settings were retained at their default values.

The tree-based species-delimitation methods were applied to a 145-taxon cytb dataset after condensing it into unique haplotypes. The Unix command-line software mptp 0.2.4 [71] was used to conduct the mPTP and PTP analyses. The options '-multi' and '-single' in the mptp software were chosen to decide the algorithm for the MPTP and PTP analyses, respectively. A ML gene tree generated by RAxML-NG was used as the starting binary tree. The MCMC analyses for both $\mathrm{mPTP}$ and PTP were run for 50 million generations, sampling every 10,000 generations, in two independent runs after removing the outgroups. The first 1,000,000 trees were discarded as burn-in and the convergence of the two runs checked by the plot of generation vs. log-likelihood.

In addition, we also calculated, using MEGA, the uncorrected pairwise $c y t b$ genetic distances for species of Pethia.

\section{Genetic diversity and population structure}

For $c y t b$ and rag1, we estimated genetic diversity within $P$. cumingii, $P$. melanomaculata, $P$. nigrofasciata, and $P$. reval by computing the number of haplotypes (h), polymorphic sites (S), parsimony-informative sites $(\mathrm{P})$, nucleotide diversities $(\pi)$ and haplotype diversities $(\mathrm{Hd})$ using DNAsp v.6 [80]. The neutrality tests, Tajima's D [81] and $\mathrm{Fu}$ and Li's F [82], were conducted using DNAsp v.6 to explore demographic changes in the above-mentioned four species of Pethia. The haplotype networks for $c y t b$ and rag1 for these four species were constructed through a Median-Joining Network [83] in PopArt [84].

\section{Morphometry, meristics and statistical analysis}

Metric and meristic data were obtained from the examination of a total of 386 and 380 specimens, respectively, following the methods of Sudasinghe et al. [4]. All bilateral measurements were taken point-to-point on the left side of specimens using a digital caliper to the nearest $0.1 \mathrm{~mm}$. The number in parentheses after a count indicates the frequency of that count. Specimens examined (Additional file 1: Table S4) are deposited in the collection of the Wildlife Heritage Trust of Sri Lanka (WHT), now at the National Museum of Sri Lanka, Colombo, Sri Lanka (NH); the Evolutionary Ecology and Systematics Lab, Department of Molecular Biology and Biotechnology, University of Peradeniya, Peradeniya, Sri Lanka (DZ); the collection of Maurice Kottelat, Delémont, Switzerland (CMK); and the Zoological Reference Collection, Lee Kong Chian Natural History Museum, National University of Singapore, Singapore (ZRC).

All the measurements showed a positive correlation with the standard length. Therefore, size correction for the measurements was done using the equation,

$$
M_{s}=M_{o}\left(\frac{L_{s}}{L_{o}}\right)^{b}
$$

where the standardized measurement and the measured character length are represented by $M_{s}$ and $M_{o}$, respectively, $L_{o}$ is the standard length of each specimen, and $L_{s}$ is the overall (arithmetic) mean standard length for all individuals from all populations of all the species. The value of $b$ for each character from the observed data was estimated using the allometric-growth equation 
$M=a L^{b}$, where $b$ is the gradient of regression of $\log M_{o}$ on $\log L_{o}$ [85].

Principal component analyses (PCA) using a correlation matrix were carried out to visualize and summarize multivariate morphometric data in a few dimensions and to assess whether the different species of Pethia and geographic subgroups form distinct clusters. A multiple correspondence analysis (MCA) was carried out to visualize and summarize the most variable meristic data (scale counts) in a few dimensions and to assess whether the different species and subgroups of Pethia form distinct clusters. The fin-ray counts were excluded from the MCA as they were invariable among all the species examined. All statistical analyses were done using R Studio 4.0.0 [86] and the R package FactoMineR (version 1.34) was used for the PCA and MCA [87].

\begin{abstract}
Abbreviations
ABGD: Automatic Barcode Gap Discovery; a.s.l: Above sea level; BI: Bayesian Inference; BIC: Bayesian information criterion; BP: Felsenstein's bootstrap support; bp: Base pairs; cytb: cytochrome b; kya: Thousand years ago; MCA: Multiple correspondence analysis; MCMCMC: Metropolis coupled Markovchain Monte Carlo; ML: Maximum Likelihood; mPTP: Multi-rate Poisson Tree Processes; My: Million years ago; m/y: Meters per year; PCA: Principal component analysis; PCR: Polymerase chain reaction; PP: Bayesian posterior probability; PTP: Poisson Tree Processes; rag 1: recombination activating gene 1; SL: Standard length; s.S: Sensu stricto.
\end{abstract}

\section{Supplementary Information}

The online version contains supplementary material available at https://doi. org/10.1186/s12862-021-01923-5.

Additional file 1: Fig. S1. Molecular phylogenetic relationships of Pethia, based on Bayesian inference of the cytb (1082 bp) data set. Asterisks $\left(^{*}\right)$ above and below nodes represent $\geq 95 \%$ Bayesian posterior probabilities and ML bootstrap values, respectively. Scale bar represents number of changes per site. Node support below 50 is not labeled. Fig. S2. Molecular phylogenetic relationships of Pethia, based on Bayesian inference of the ragl (1490 bp) data set. Asterisks (*) above and below nodes represent $\geq 95 \%$ Bayesian posterior probabilities and ML bootstrap values, respectively. Scale bar represents number of changes per site Node support below 50 is not labeled. Table S1. Valid species of Pethia, with their type localities, distinguishing characters and distribution. Table S2. The comparative genetic dataset representative of Smiliogastrinae and outgroups downloaded from GenBank. Table S3. Nucleotide substitution models and the partitions used in the phylogenetic analyses. Table S4. Specimens of Pethia examined for the morphological analysis. LK, Sri Lanka; IND, India. Table S5. Intraspecific uncorrected pairwise cytb genetic distances for species of Pethia in Sri Lanka. Table S6. Genetic diversity, based on cytb and rag1, in Sri Lankan species of Pethia. Number of sequences (N), number of haplotypes (h), polymorphic sites $(\mathrm{S})$, parsimony-informative sites $(\mathrm{P})$, nucleotide diversity $(\pi)$, haplotype diversity $(\mathrm{Hd})$. None of the neutrality tests were statistically significant. Table S7. Component loadings in the principal component analysis of the size-adjusted morphometric measurements of species of Pethia in Sri Lanka. Table S8. Proportional morphometric data for the species of Pethia in Sri Lanka. Table S9. Frequency distribution of selected meristic data in the Sri Lankan species of Pethia examined in the present study. Table S10. Proportional morphometric data for Pethia bandula, P. nigrofasciata (excluding Attanagalu populations), and P. cf. nigrofasciata (Attanagalu population). Table S11. Proportional morphometric data for Pethia reval, P. cumingii (Bentara and Gin populations), and P. cf. cumingii (Kalu population) in Sri Lanka.

\section{Acknowledgements}

HS and MM are grateful to the Director General of Wildlife Conservation and the Conservator General of Forests, Sri Lanka, for permits to carry out fieldwork. HS thanks Maurice Kottelat for allowing access to the type series of Pethia bandula for this study; the Wildlife Heritage Trust of Sri Lanka for financial support. HS and TR would like to thank Charana Widuranga, Dhanushka Lakshan, Kasthuri Krishantha, Supun Chandana and Wasantha Kumara for assistance in the field. Finally, we would like to thank the two anonymous reviewers for their constructive comments that greatly helped to improve the MS.

\section{Authors' contributions}

$\mathrm{HS}, \mathrm{RP}, \mathrm{MM}$ conceptualized the research and designed the methodology. HS $\mathrm{TR}, \mathrm{JH}, \mathrm{KW}$ conducted fieldwork and curated the data. HS carried out formal analysis and writing original draft. RP, LR, MM review and editing, supervision and funding acquisition. All authors read and approved the manuscript.

\section{Funding}

Funding for this study was partly provided by the Wildlife Heritage Trust of Sri Lanka to HS.

\section{Availability of data and materials}

All data generated or analyzed during this study or the sources of data (GenBank) are included in this published article.

\section{Declarations}

\section{Ethics approval and consent to participate}

Field work and sampling in Sri Lanka were carried out by permission of the Department of Wildlife Conservation (permit no. WL/3/2/59/14) and Forest Department (permit no. R\&E/RES/NFSRCM/14-16-4) to HS and MM. Methods of sampling and euthanasia (using tricaine methane sulfonate) were approved by the ethics committee of the Postgraduate Institute of Science, University of Peradeniya, at its 27th meeting held on 4 August 2017.

\section{Consent for publication}

Not applicable.

\section{Competing interests}

The authors declare that they have no competing interests.

\section{Author details}

${ }^{1}$ Evolutionary Ecology and Systematics Laboratory, Department of Molecular Biology and Biotechnology, University of Peradeniya, Peradeniya 20400, Sri Lanka. ${ }^{2}$ Postgraduate Institute of Science, University of Peradeniya, Peradeniya 20400, Sri Lanka. ${ }^{3}$ Evolutionary Ecology, Institute of Ecology and Evolution, University of Bern, 3012 Bern, Switzerland. ${ }^{4}$ Naturhistorisches Museum Bern, Bernastrasse, 15, 3005 Bern, Switzerland. ${ }^{5}$ Butterfly Conservation Society of Sri Lanka, 762/A, Yatihena, Malwana 11670, Sri Lanka. ${ }^{6}$ Guangxi Key Laboratory for Forest Ecology and Conservation, College of Forestry, Guangxi University, Nanning 530004, Guangxi, People's Republic of China. ${ }^{7}$ Department of Zoology, Faculty of Science, University of Peradeniya, Peradeniya 20400, Sri Lanka. ${ }^{8}$ Ichthyology Section, Australian Museum, 6 College Street, Sydney, NSW 2010, Australia. ${ }^{9}$ Aquatic Ecology and Evolution, Institute of Ecology and Evolution, University of Bern, 3012 Bern, Switzerland.

Received: 25 June 2021 Accepted: 29 September 2021 Published online: 10 November 2021

\section{References}

1. Bossuyt F, Meegaskumbura M, Beenaerts N, Gower DJ, Pethiyagoda R, Roelants K, et al. Local endemism within the Western Ghats-Sri Lanka biodiversity hotspot. Science. 2004;306:479-81.

2. Gunatilleke N, Pethiyagoda R, Gunatilleke S. Biodiversity of Sri Lanka. J Natl Sci Found Sri Lanka. 2008;36:25-61.

3. Miller KG, Browning JV, Schmelz WJ, Kopp RE, Mountain GS, Wright JD. Cenozoic sea-level and cryospheric evolution from deep-sea geochemical and continental margin records. Sci Adv. 2020;6:eaaz1346. 
4. Sudasinghe H, Ranasinghe RHT, de Goonatilake SA, Meegaskumbura M. A review of the genus Labeo (Teleostei: Cyprinidae) in Sri Lanka. Zootaxa. 2018;4486:201-35.

5. Sudasinghe H, Dahanukar N, Raghavan R, Senavirathna T, Shewale DJ, Paingankar MS, et al. Island colonization by a'rheophilic' fish: the phylogeography of Garra ceylonensis (Teleostei: Cyprinidae) in Sri Lanka. Biol J Linn Soc. 2021;132:872-93.

6. Chatterjee S, Goswami A, Scotese CR. The longest voyage: tectonic, magmatic, and paleoclimatic evolution of the Indian plate during its northward flight from Gondwana to Asia. Gondwana Res. 2013;23:238-67.

7. Senevirathne G, Samarawickrama VAMPK, Wijayathilaka N, Manamendra-Arachchi K, Bowatte G, Samarawickrama DRNS, et al. A new frog species from rapidly dwindling cloud forest streams of Sri Lanka - Lankanectes pera (Anura, Nyctibatrachidae). Zootaxa. 2018;4461:519-38.

8. Reuter M, Harzhauser M, Piller WE. The role of sea-level and climate changes in the assembly of Sri Lankan biodiversity: a perspective from the Miocene Jaffna Limestone. Gondwana Res. 2021;91:152-65.

9. Myers N, Mittermeier RA, Mittermeier CG, da Fonseca GAB, Kent J. Biodiversity hotspots for conservation priorities. Nature. 2000:403:853-8.

10. Sudasinghe H, Raghavan R, Dahanukar N, Pethiyagoda R, Rüber L, Meegaskumbura M. Diversification and biogeography of Dawkinsia (Teleostei: Cyprinidae) in the Western Ghats-Sri Lanka Biodiversity Hotspot. Org Divers Evol. 2021. https://doi.org/10.1007/s13127-021-00515-x.

11. Sudasinghe H, Pethiyagoda R, Raghavan R, Dahanukar N, Rüber L, Meegaskumbura M. Diversity, phylogeny and biogeography of Systomus (Teleostei, Cyprinidae) in Sri Lanka. Zool Scr. 2020:49:710-31.

12. Meegaskumbura M, Senevirathne G, Manamendra-Arachchi K, Pethiyagoda R, Hanken J, Schneider CJ. Diversification of shrub frogs (Rhacophoridae, Pseudophilautus) in Sri Lanka-timing and geographic context. Mol Phylogenet Evol. 2019;132:14-24.

13. Beenaerts N, Pethiyagoda R, Ng PKL, Yeo DCJ, Bex GJ, Bahir MM, et al. Phylogenetic diversity of Sri Lankan freshwater crabs and its implications for conservation. Mol Ecol. 2010;19:183-96.

14. Sudasinghe H, Pethiyagoda R, Meegaskumbura M. Evolution of Sri Lanka's Giant Danios (Teleostei: Cyprinidae: Devario): teasing apart species in a recent diversification. Mol Phylogenet Evol. 2020;149:106853.

15. Sudasinghe H, Pethiyagoda R, Ranasinghe RHT, Raghavan R, Dahanukar N, Meegaskumbura M. A molecular phylogeny of the freshwaterfish genus Rasbora (Teleostei: Cyprinidae) in Sri Lanka reveals a remarkable diversification-and a cryptic species. J Zool Syst Evol Res. 2020;58:1076-110.

16. Pethiyagoda R, Maduwage K, Meegaskumbura M. A synopsis of the South Asian fishes referred to Puntius (Pisces: Cyprinidae). Ichthyol Explor Freshw. 2012;23:69-95.

17. Fricke R, Eschmeyer WN, Van der Laan R. Eschmeyer's catalog of fishes: Genera, species, references; 2021. http://researcharchive.calacademy.org/ research/ichthyology/catalog/fishcatmain.asp. Accessed 16 May 2021

18. Conway KW, Pinion AK, Kottelat M. Two new species of Pethia (Teleostei: Cyprinidae), representing a sympatric species pair, from the Ayeyarwady drainage, Myanmar. Raffles Bull Zool. 2021;69:80-101.

19. Katwate U, Kumkar P, Raghavan R, Dahanukar N. A new syntopic species of small barb from the Western Ghats of India (Teleostei: Cyprinidae). Zootaxa. 2018;4434:529-46.

20. Kottelat M. The fishes of the inland waters of Southeast Asia: a catalogue and core bibliography of the fishes known to occur in freshwaters, mangroves and estuaries. Raffles Bull Zool. 2013;27:1-663.

21. Shangningam B, Kosygin L, Chowdhury BR. Pethia arunachalensis, a new species of small barb (Teleostei: Cyprinidae) from Arunachal Pradesh, India. Rec Zool Surv India. 2019;119:328-33.

22. Pethiyagoda R. Freshwater fishes of Sri Lanka. Colombo: Wildlife Heritage Trust; 1991

23. Katwate U, Paingankar MS, Raghavan R, Dahanukar N. Pethia longicauda, a new species of barb (Teleostei: Cyprinidae) from the northern Western Ghats, India. Zootaxa. 2014;3846:235-48.

24. Katwate U, Jadhav S, Kumkar P, Raghavan R, Dahanukar N. Pethia sanjaymoluri, a new species of barb (Teleostei: Cyprinidae) from the northern Western Ghats, India. J Fish Biol. 2016;88:2027-50.

25. Ren Q, Yang L, Chang C, Mayden RL. Molecular phylogeny and divergence of major clades in the Puntius complex (Teleostei: Cypriniformes). Zool Scr. 2020;49:697-709.
26. Ren Q, Mayden RL. Molecular phylogeny and biogeography of African diploid barbs, 'Barbus', and allies in Africa and Asia (Teleostei: Cypriniformes). Zool Scr. 2016:45:642-9.

27. Batuwita S, Maduwage K, Sudasinghe H. Redescription of Pethia melanomaculata (Teleostei: Cyprinidae) from Sri Lanka. Zootaxa. 2015;3936:575-83.

28. Meegaskumbura M, Silva A, Maduwage K, Pethiyagoda R. Puntius reval, a new barb from Sri Lanka (Teleostri: Cyprinidae). Ichthyol Explor Freshw. 2008;19:141-52.

29. Kottelat M, Pethiyagoda R. Description of three new species of cyprinid fishes from Sri Lanka. Freshwater fishes of Sri Lanka. Colombo: Wildlife Heritage Trust; 1991. p. 299-313.

30. Katwate U, Baby F, Raghavan R, Dahanukar N. The identity of Pethia punctata, a senior synonym of $P$. muvattupuzhaensis (Teleostei: Cyprinidae). Zootaxa. 2014;3884:201-21.

31. Katwate U, Raghavan R, Dahanukar N. The identity of Hamilton's Ticto Barb, Pethia ticto (Teleostei: Cyprinidae). Zootaxa. 2015;3964:401-18.

32. Deraniyagala PEP. The eventognathi of Ceylon. Spolia Zeylan. 1930;16:1-41.

33. Sudasinghe $\mathrm{H}$, Herath J, Pethiyagoda R, Meegaskumbura M. Undocumented translocations spawn taxonomic inflation in Sri Lankan fire rasboras (Actinopterygii, Cyprinidae). PeerJ. 2018;6:e6084

34. Wikramanayake ED. Conservation of endemic rain forest fishes of Sri Lanka: results of a translocation experiment. Conserv Biol. 1990;4:32-7.

35. de Queiroz K. The general lineage concept of species, species criteria, and the process of speciation: a conceptual unification and terminological recommendations. In: Howard DJ, Berlocher SH, editors. Endless forms: species and speciation. New York: Oxford University Press; 1998. p. 57-75.

36. Hora SL. Notes on fishes in the Indian Museum. XXVIII. On three collections of fish from Mysore and Coorg, South India. Rec Indian Mus Calcutta. 1937;39:5-28.

37. Katwate U, Kumkar P, Raghavan R, Dahanukar N. Taxonomy and systematics of the 'Maharaja Barbs' (Teleostei: Cyprinidae), with the description of a new genus and species from the Western Ghats, India. Zootaxa. 2020;4803:544-60.

38. Knight JDM. Pethia aurea (Teleostei: Cyprinidae), a new species of barb from West Bengal, India, with redescription of P. gelius and P. canius. Zootaxa. 2013;3700:173-84

39. Sudasinghe H, Pethiyagoda R, Meegaskumbura M. A molecular phylogeny of the genus Laubuka (Teleostei: Cyprinidae) in Sri Lanka reveals multiple origins and a cryptic species. Syst Biodivers. 2020;1 18:592-613.

40. Sudasinghe $H$, Pethiyagoda R, Meegaskumbura M. A review of the genus Esomus in Sri Lanka (Teleostei: Cyprinidae). Ichthyol Explor Freshw. 2019:29:343-60.

41. Sudasinghe H, Pethiyagoda R, Meegaskumbura M, Maduwage K, Britz R. Channa kelaartii, a valid species of dwarf snakehead from Sri Lanka and southern peninsular India (Teleostei: Channidae). Vertebr Zool. 2020;70:157-70.

42. Sudasinghe $H$, Adamson EAS, Ranasinghe RHT, Meegaskumbura M, Ikebe C, Britz R. Unexpected species diversity within Sri Lanka's snakehead fishes of the Channa marulius group (Teleostei: Channidae). Zootaxa. 2020;4747:113-32.

43. Sudasinghe H, Pethiyagoda R, Maduwage K, Meegaskumbura M. The identity of the Sri Lankan Amblypharyngodon (Teleostei, Cyprinidae). ZooKeys. 2019;820:25-49.

44. Dean LL, Magalhaes IS, Foote A, D'Agostino D, McGowan S, MacColl ADC. Admixture between ancient lineages, selection, and the formation of sympatric stickleback species-Pairs. Mol Biol Evol. 2019;36:2481-97.

45. Guo B, Fang B, Shikano T, Momigliano P, Wang C, Kravchenko A, et al. A phylogenomic perspective on diversity, hybridization and evolutionary affinities in the stickleback genus Pungitius. Mol Ecol. 2019;28:4046-64.

46. del Pedraza-Marrón CR, Silva R, Deeds J, van Belleghem SM, MastrettaYanes A, Domínguez-Domínguez O, et al. Genomics overrules mitochondrial DNA, siding with morphology on a controversial case of species delimitation. Proc R Soc B Biol Sci. 2019;286:20182924.

47. Toews DPL, Brelsford A. The biogeography of mitochondrial and nuclear discordance in animals: biogeography of mito-nuclear discordance. Mol Ecol. 2012;21:3907-30.

48. IUCN. The IUCN red list of threatened species. Version 2019-1. 2021. http://www.iucnredlist.org. Accessed 2 May 2019. 
49. Sudasinghe H, Meegaskumbura M. Ompok argestes, a new species of silurid catfish endemic to Sri Lanka (Teleostei: Siluridae). Zootaxa. 2016;4158:261-71.

50. Avise JC. Phylogeography: the history and formation of species. Cambridge: Harvard University Press; 2000.

51. Ashton P. On the forests of tropical Asia: lest the memory fade. Kew: Royal Botanic Gardens; 2014.

52. Potter S, Afonso Silva AC, Bragg JG, Catalano SR, Donnellan S, Doughty $P$, et al. Contrasting scales of local persistence between monsoonal and arid biomes in closely related, low-dispersal vertebrates. J Biogeogr. 2019:46:2506-19.

53. Sudasinghe $H$, Ranasinghe RHT, Pethiyagoda R, Meegaskumbura M, Britz R. Genetic diversity and morphological stasis in the Ceylon Snakehead, Channa orientalis (Teleostei: Channidae). Ichthyol Res. 2020;68:67-80.

54. de Silva KHGM, Somarathna RMD. Food and feeding biology of the endemic carplets Barbus cumingi and B. nigrofasciatus (Osteichthyes, Cyprinidae) of Sri Lanka. Ceylon J Sci Biol Sci. 1994;23:12-24.

55. De Silva KHGM, Somarathna RMD. Reproductive ecology of two cooccurring, stream-dwelling, endemic carplets (Pisces, Cyprinidae) of Sri Lanka. Ceylon J Sci Biol Sci. 1994;23:1-11.

56. Kumar S, Stecher G, Tamura K. MEGA7: molecular evolutionary genetics analysis version 7.0 for bigger Datasets. Mol Biol Evol. 2016;33:1870-4.

57. Katwate U, Knight JDM, Anoop VK, Raghavan R, Dahanukar N. Three new species of filament barbs of the genus Dawkinsia (Teleostei: Cyprinidae) from the Western Ghats of India. Vertebr Zool. 2020;70:207-33.

58. Katwate U, Katwate C, Raghavan R, Paingankar MS, Dahanukar N. Pethia lutea, a new species of barb (Teleostei: Cyprinidae) and new records of P. punctata from northern Western Ghats of India. J Threat Taxa. 2014;6:5797-818.

59. Villesen P. FaBox: an online toolbox for fasta sequences. Mol Ecol Notes, 2007;7:965-8

60. Zhang D, Gao F, Jakovlić I, Zou H, Zhang J, Li WX, et al. PhyloSuite: an integrated and scalable desktop platform for streamlined molecular sequence data management and evolutionary phylogenetics studies. Mol Ecol Resour. 2020;20:348-55.

61. Kozlov AM, Darriba D, Flouri T, Morel B, Stamatakis A. RAxML-NG: a fast, scalable and user-friendly tool for maximum likelihood phylogenetic inference. Bioinformatics. 2019;35:4453-5.

62. Ronquist F, Teslenko M, van der Mark P, Ayres DL, Darling A, Höhna S, et al. MrBayes 3.2: efficient Bayesian phylogenetic inference and model choice across a large model space. Syst Biol. 2012;61:539-42.

63. Miller MA, Pfeiffer W, Schwartz T. Creating the CIPRES Science Gateway for inference of large phylogenetic trees. 2010 Gateway Computing Environments Workshop (GCE). New Orleans: IEEE; 2010. pp. 1-8. https://doi.org/ 10.1109/GCE.2010.5676129

64. Lanfear R, Frandsen PB, Wright AM, Senfeld T, Calcott B. PartitionFinder 2: new methods for selecting partitioned models of evolution for molecular and morphological phylogenetic analyses. Mol Biol Evol. 2017;34:772-3.

65. Lanfear R, Calcott B, Ho SYW, Guindon S. PartitionFinder: combined selection of partitioning schemes and substitution models for phylogenetic analyses. Mol Biol Evol. 2012;29:1695-701.

66. Guindon S, Dufayard JF, Lefort V, Anisimova M, Hordijk W, Gascuel O. New algorithms and methods to estimate maximum-likelihood phylogenies: assessing the performance of PhyML 3.0. Syst Biol. 2010;59:307-21.

67. Rambaut A, Suchard MA, Xie D, Drummond AJ. Tracer; 2014. http://tree. bio.ed.ac.uk/software/tracer/.

68. Huelsenbeck JP, Ronquist F, Nielsen R, Bollback JP. Bayesian inference of phylogeny and its impact on evolutionary biology. Science. 2001;294:2310-4
69. Darriba D, Posada D, Kozlov AM, Stamatakis A, Morel B, Flouri T. ModelTest-NG: a new and scalable tool for the selection of dna and protein evolutionary models. Mol Biol Evol. 2020;37:291-4.

70. Fujisawa T, Barraclough TG. Delimiting species using single-locus data and the generalized mixed yule coalescent approach: a revised method and evaluation on simulated data sets. Syst Biol. 2013;62:707-24.

71. Kapli P, Lutteropp S, Zhang J, Kobert K, Pavlidis P, Stamatakis A, et al. Multirate Poisson tree processes for single-locus species delimitation under maximum likelihood and Markov chain Monte Carlo. Bioinformatics. 2017;33:1630-8.

72. Pons J, Barraclough TG, Gomez-Zurita J, Cardoso A, Duran DP, Hazell S, et al. Sequence-based species delimitation for the DNA taxonomy of undescribed insects. Syst Biol. 2006;55:595-609.

73. Puillandre N, Lambert A, Brouillet S, Achaz G. ABGD, automatic barcode gap discovery for primary species delimitation. Mol Ecol. 2012;21:1864-77.

74. Tang CQ, Humphreys AM, Fontaneto D, Barraclough TG. Effects of phylogenetic reconstruction method on the robustness of species delimitation using single-locus data. Methods Ecol Evol. 2014;5:1086-94.

75. Zhang J, Kapli P, Pavlidis P, Stamatakis A. A general species delimitation method with applications to phylogenetic placements. Bioinformatics. 2013;29:2869-76.

76. Blair C, Bryson RW. Cryptic diversity and discordance in single-locus species delimitation methods within horned lizards (Phrynosomatidae: Phrynosoma). Mol Ecol Resour. 2017;17:1168-82.

77. Kekkonen M, Mutanen M, Kaila L, Nieminen M, Hebert PDN. Delineating species with DNA barcodes: a case of taxon dependent method performance in moths. PLOS ONE. 2015;10:e0122481.

78. Kekkonen M, Hebert PDN. DNA barcode-based delineation of putative species: efficient start for taxonomic workflows. Mol Ecol Resour. 2014;14:706-15.

79. Sholihah A, Delrieu-Trottin E, Sukmono T, Dahruddin H, Risdawati R, Elvyra R, et al. Disentangling the taxonomy of the subfamily Rasborinae (Cypriniformes, Danionidae) in Sundaland using DNA barcodes. Sci Rep. 2020;10:2818.

80. Rozas J, Ferrer-Mata A, Sánchez-DelBarrio JC, Guirao-Rico S, Librado P, Ramos-Onsins SE, et al. DnaSP 6: DNA sequence polymorphism analysis of large data sets. Mol Biol Evol. 2017;34:3299-302.

81. Tajima F. Statistical method for testing the neutral mutation hypothesis by DNA polymorphism. Genetics. 1989;123:585-95.

82. Fu YX, LiWH. Statistical tests of neutrality of mutations. Genetics. 1993;133:693-709.

83. Bandelt HJ, Forster P, Röhl A. Median-joining networks for inferring intraspecific phylogenies. Mol Biol Evol. 1999;16:37-48.

84. Leigh JW, Bryant D. POPART: full-feature software for haplotype network construction. Methods Ecol Evol. 2015;6:1110-6.

85. Elliott NG, Haskard K, Koslow JA. Morphometric analysis of orange roughy (Hoplostethus atlanticus) off the continental slope of southern Australia. J Fish Biol. 1995;46:202-20.

86. R Core Team. R: a language and environment for statistical computing. Vienna, Austria: R foundation for statistical computing; 2020. https:// www.R-project.org.

87. Lê S, Josse J, Husson F. FactoMineR: an R package for multivariate analysis. J Stat Softw. 2008;25:1-18.

\section{Publisher's Note}

Springer Nature remains neutral with regard to jurisdictional claims in published maps and institutional affiliations. 